\title{
Gelişimi Risk Altında Olan Okul Öncesi Dönem Çocuklarının Sosyal Beceri Düzeylerinin Değerlendirilmesi
}

\author{
The Evaluation of the Social Skills Levels of Pre-School Children whose \\ Development is Under Risk
}

\section{Duygu ÇETINGÖZ* S. Sunay YILDIRIM DOĞRU**}

\begin{abstract}
$\ddot{O}_{z}: \mathrm{Bu}$ çalışmanın amacı gelişimi risk altında olan okul öncesi dönem çocuklarının sosyal beceri düzeylerinin değerlendirilmesidir. Araştırmanın evrenini, İzmir ili merkez ilçelerinde Milli Eğitim Bakanlığına bağlı ilkokulların anasınıflarına devam eden 5-6 yaş çocukları oluşturmuştur. Araştırma grubu oluşturulurken, alt sosyo-ekonomik düzeyi temsil eden okullardaki çocuklara ulaşılmıştır. Ancak bu okullar dağını bir şekilde bulundukları için ilçelerden Buca ve Çiğli seçilmiştir. Bu ilkokullar arasından küme örnekleme yöntemi ile Buca ve Çiğli ilçesindeki alt sosyo-ekonomik düzeydeki okullar belirlenmiştir. Belirlenen okullara devam eden, anasınıfı çocuklarından $60 \mathrm{kız}, 75$ erkek olmak üzere toplam 135, 5-6 yaş çocukları araştırmanın örneklemini oluşturmuştur. Araştırma betimsel bir çalışma olup genel tarama modelline göre yapılmıştır. Araştırmada Avcıoğlu (2007) tarafindan geliştirilmiş olan "4-6 Yaş Sosyal Beceri Değerlendirme Ölçeği” ve araştırmacılar tarafindan geliştirilen "Aile Demografik Bilgi Formu" kullanılmıştır. Araştırmanın sonunda gelişimi risk altında olan okul öncesi çocuklarının sosyal beceri düzeylerinin düşük olduğu, gelişimi risk altında olan okul öncesi çocuklarının sosyal beceri düzeylerinin engel durumlarına, ailenin sosyo-kültürel özelliklerine, çocuğun yaşadığı ortama göre farklılıklar gösterdiği belirlenmiştir.
\end{abstract}

Anahtar sözcükler: Gelişimi Risk Altında Olan, Okul Öncesi Dönem, Sosyal Beceri, Değerlendirme

Abstract: The aim of this study was to evaluate the social skills levels of pre-school children whose development is at risk. This study concerns 5 to 6 year old children who attend pre-school classes of elementary schools of the National Ministry of Education in central Izmir. The chosen research group was those children who attend schools which represent lower socio economic status. The research groups of elementary schools were determined through the random cluster sampling method. The lower socio economic group schools were chosen in the Buca and Çiğli regions of İzmir. The research group comprised 135, 5 to 6 year old children, 60 girls and 75 boys. These children were randomly chosen in the schools. This was a descriptive study conducted by general survey method. The instruments utilized were the "Social Skills Evaluation Scale for 4-6 Years Old Children" developed by Avcioğlu (2007) and the "Family Demographic Information Form" developed by the researchers. The results reveal that social skills levels of pre-school children whose development is under risk are low and that the social skills levels of preschool children whose development is under risk differ, depending upon their disability, the socio cultural qualities of their families and the given environment that these children inhabit.

Keywords: Development is Under Risk, Pre-school Children, Social Skills, Evaluation

\footnotetext{
${ }^{*}$ Yrd. Doç. Dr., Dokuz Eylül Üniv., Buca Eğitim Fak., Okul Öncesi Eğitimi A.B.D., İzmir. duygucetingoz@gmail.com

*** Prof. Dr., Dokuz Eylül Üniversitesi, Buca Eğitim Fakültesi, Özel Eğitim Bölümü, İzmir. s.y.dogru@gmail.com Bu makale 31 Mart-3 Nisan 2016 tarihinde 3. Ulusal Erken Çocuklukta Müdahale Kongresinde poster bildiri olarak sunulmuştur.
} 


\section{Giriş}

Günümüzde çocuğun gelişiminin sadece kalıtımsal etmenlere ya da sadece çevre faktörüne dayanarak açıklayan tek taraflı görüşler artık önemini yitirmiştir. Toplumsal çevre koşullarının da çocuğun gelişmesinde önemli rolü olduğunu vurgulayan ve özellikle yaşamın ilk yıllarında

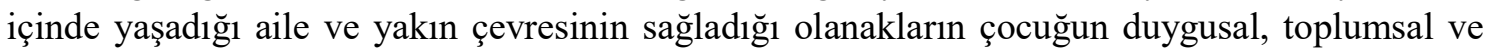
zihinsel gelişimindeki rolüne değinen görüşler önem kazanmaktadır (Oktay 1999). Ailenin ve yakın çevrenin sağladığı olanaklar ise her çocuk için eşit şekilde olmamaktadır. Özellikle işsizlik, hastalıklar, yoksulluk gibi çevresel risk koşullarının tümü, bu koşularda yetişen çocukların geleceğini tehdit eden risk etmenleri olarak görülmektedir (Berk 1997). Bu risk etmenleri çocukların gelişimlerini de riskli hale getirmektedir. Örneğin yoksulluk öğeleri olarak sağlıksız çevre, sağlıksız kalabalık konut, sınırlı eğitim, parasal yetersizlik, işsizlik gibi risk etmenleri çocukların gelişimleri için risk niteliği teşkil etmektedirler (Durgun 2011). Yoksulluk, insanların sadece gelir ve tüketim gibi maddi nesnelerden (beslenme, barınma, giyinme vb.) yoksun olmalarını değil, aynı zamanda sağlık, eğitim, ulaştırma, sosyal güvence ve toplumsal faaliyetlerdeki hizmetleri de elde edememelerini ifade etmektedir (Arpacıŏglu \& Yıldırım 2011; Taş \& Özcan 2012). Ayrıca günümüz koşullarında yoksulluk sadece gelir yetersizliği ile açıklanabilecek bir sorun olmaktan çıkmış, bireyin toplumsal kaynaklara erişememesi ve bu nedenle topluma aktif olarak katılamaması yani bir sosyal dışlanma sorunu haline gelmiştir ( $\operatorname{Er} 2014)$.

Ailesi ile birlikte yaşayan alt sosyo-ekonomik düzeyden gelen çocuklarda yaşıtlarına göre gerilikler olabilmektedir (Akman 2002). Yoksulluk çeken ailelerin çocuklarında sağlık problemleri, bilişsel gelişimde yavaşlamalar ve davranış problemleri daha sık gözlenmektedir (Wise \& Meyers 1988; akt. Akman 2002). Yoksul çocuklar yoksul olmayan çocuklara göre öfke, kavga etme, sosyal olarak geri çekilme, endişe gibi duygusal ve davranışsal problemlerden daha s1k şikayet ederler (Er 2014). Beş yaşında düşük doğum ağırlığı olan çocuklar üzerinde yapılan bir çalışmada sürekli yoksul olan ailelerin çocuklarının yoksul olmayan ailelerin çocuklarına göre daha fazla dışa ve içe dönük davranış problemleri olduğu bulunmuştur (Brooks-Gunn \& Duncan 1997).

Okul öncesi dönemde gözlenen davranış problemlerinin bir nedeni de çocuğun birtakım sosyal becerileri kazanamamış olmasına dayanmaktadır. Kişilerarası ilişkilerde ilişkilerin kurulmasını, sürdürülmesini ve problemlerin çözülmesini kapsayan (Cowie 2012) sosyal becerilerin gelişimi çocuğun çeşitli bilişsel ve davranışsal yetenekler edinmesini gerektirir (Uysal \& Akman 2015). Ancak çocuğun içinde bulunduğu olumsuz koşullar, risk etmenleri ve model almada yaşayabileceği güçlükler sosyal becerilerin kazanılmasında etkili olan bilişsel ve davranışsal yeteneklerin gelişmesine ve yeterince kullanılmasına engel olabilmektedir. Bu durumun olumsuz etkilerini en az düzeye indirmek için risk altındaki erken çocukluk dönemi çocuklarını hedefleyen erken müdahale programları uygulamaktadır.

Erken müdahale programlarıyla risk altındaki çocukların sosyal beceriler yönünden eksikliklerine ve sorun davranışlarına erken çocukluk döneminde müdahale edilmesi sosyal olarak yetkin bireyler haline gelmelerine firsat tanımaktadır. Paylaşma, yardımlaşma, işbirliği yapma, sırasını bekleme gibi temel sayılan becerilere sahip olmayan çocuklar akranlarını anlamakta güçlük çekmekte, bu da onları saldırganlık, zorbalık, şiddet içeren davranışları kullanmaya itmektedir. Bu davranışları karşılığında ise akranları tarafından reddedilmektedirler. Sorun davranışlara müdahale edilmemesi halinde akademik başarısızlık kalıcı hale gelerek yetişkinlikte de çeşitli problemlere yol açmaktadır. Bu doğrultuda çocukların sosyal yönden güçlendirilmesi için yapılacak erken müdahale çalışmaları gelecekte de topluma uyum sağlayabilen bireylerin yetiştirilmesi açısından oldukça önemlidir (Uysal \& Akman 2015). 
Buraya kadar yapılan açıklamalara dayalı olarak bu çalışmada gelişimi risk altında olan okul öncesi dönem çocuklarının sosyal beceri düzeylerinin belirlemesi ve bu düzeylerin çocuğun engel durumuyla, aile demografik özellikleri ile ilişkisinin değerlendirilmesi amaçlanmaktadır.

\section{Yöntem}

\section{Araştırmanın Örneklemi}

Araştırmanın evrenini, İzmir ili merkez ilçelerinde Milli Eğitim Bakanlığına bağlı ilkokullarının anasınıflarına devam eden 5-6 yaş çocukları oluşturmuştur. Araştırma grubunu gelişimi risk altındaki çocuklardan oluşturmak için sosyo-ekonomik düzey değişkeninin kontrol altında tutulması amaçlanmıştır. Bu nedenle İzmir ili Buca ve Çiğli ilçesinde alt sosyo-ekonomik düzeyi temsil eden ilkokullardaki çocuklara ulaşılmıştır. Örneklemin oluşturulmasında, ilk olarak, ilkokullar belirlenmiştir. Bunun için İzmir il ve ilçe Milli Eğitim Müdürlüklerinden mevcut İzmir il merkezi ilçelerine bağlı okulların listesi elde edilmiştir. Bu listeden, alt sosyo-ekonomik düzeyi temsil eden ilkokullar arasından küme örnekleme yöntemi ile okullar belirlenmiştir. Ancak bu okullar dağınık bir şekilde bulunduklanı için ilçelerden Buca ve Çiğli seçilmiştir. Belirlenen okullara devam eden, anasınıfı çocuklarından $60 \mathrm{kız}, 75$ erkek olmak üzere toplam 135, 5-6 yaş çocukları araştırmanın örneklemini oluşturmuştur.

\section{Araştırma Modeli}

Araştırma betimsel bir çalışma olup genel tarama modellerinden ilişkisel tarama modeline göre yapılmıştır. İlişkisel tarama modeli iki ve daha çok sayıdaki değişken arasında birlikte değişimin varlığını veya derecesini belirlemeyi amaçlar (Karasar 2015). Bu araştırmanın problemi gelişimi risk altında olan okul öncesi çocuklarının sosyal beceri düzeylerinin belirlemesi ve bu düzeylerin çocuğun engel durumuyla, aile demografik özellikleri ile ilişkisinin değerlendirilmesidir. Araştırmanın problem durumuna bağlı olarak aşağıdaki araştırma sorularına yanıt aranmıştır:

1. Gelişimi risk altında olan okul öncesi çocuklarının sosyal becerileri ne düzeydedir?

2. Gelişimi risk altında olan okul öncesi çocuklarının sosyal beceri düzeyleri,

3. Çocuğun engel durumuna,

4. Ailenin sosyo-kültürel özelliklerine,

5. Çocuğun yaşadığı ortama göre farklılaşma olup olmadığına bakılmıştır.

\section{Veri Toplama Araçları}

Araştırmada Avcıŏlu (2007) tarafından geliştirilmiş olan "4-6 Yaş Sosyal Beceri Değerlendirme Ölçeği" ve "Aile Demografik Bilgi Formu" kullanılmıştır. Uygulamalar için gidilecek okullardaki gönüllü öğretmenler ve araştırmacılar bir araya gelmiştir. Aile demografik bilgi formunu ögretmenler ve araştırmacılar beraber doldurmuşlardır. Daha sonra araştırmacılar gözleme dayalı Sosyal Becerileri Değerlendirme Ölçeği hakkında öğretmenlere bilgi verilmişlerdir. Ölçeğin uygulanmasında çocukların sosyal becerileri ile ilgili bilgi elde edilmesi öğretmen görüşlerine dayalı olduğu için çocuklarla ilgili bu bilgiler öğretmenlerden elde edilmiştir.

\section{Aile Demografik Bilgi Formu}

Aile demografik bilgi formu araştırmacılar tarafindan geliştirilmiştir. Bu formda yer alan değişkenler alanyazında sosyal becerileri etkileyen etmenler olarak geçen bilgilerin bir bölümünden yararlanılarak hazırlanmıştır. Bu formda yer alan bağımsız değişkenler şöyledir; çocuğun engellik durumu, anne öğrenim düzeyi, baba öğrenim düzeyi, çocuğun daha önce okul öncesi eğitim alıp almama durumu, annenin çalışıp çalışmama durumu, sağlıksız kalabalık konutta yaşama durumu, ev ortamındaki fiziksel çevrenin durumu, evdeki psiko-sosyal ortamın durumudur. 


\section{Sosyal Becerileri Değerlendirme Ölçeği}

Avcıoğlu (2007) tarafindan 4-6 yaş okul öncesi dönem çocuklar için geliştirilmiştir. Sosyal Becerileri Değerlendirme Ölçeği, 4 ile 6 yaşlarındaki çocukların sahip olması gereken sosyal becerileri içeren beşli dereceleme şeklinde oluşturulmuş bir ölçektir. Ölçeğin kapsam geçerliğinde uzman görüşüne başvurulmuş ve uzmanlar ölçeğin sosyal becerileri ölçebilecek nitelikte olduğu yönünde görüş bildirmişlerdir. Ölçeğin yapı geçerliği açımlayıcı faktör analizi ile yapılmıştır. Ölçeğin tek boyuttan oluşup oluşmadığı Temel Bileşenler Analizi ile test edilmiştir. Ölçeğin birbirinden ilişkisiz faktörlere ayrışması beklentisi ise Varimax dik döndürme tekniği uygulanarak incelenmiştir. Temel bileşenler analiz sonucunda ölçeğin dokuz faktörden oluştuğu saptanmıştır. Bu faktörler ve faktör yükdeğerleri ile açıkladıkları varyanslar; kişilerarası beceriler $(.75-.41, \% 13,27)$, kızgınlık davranışlarını kontrol etme ve değişikliklere uyum sağlama becerileri (.86-.44, \%12,07), akran baskısı ile başa çıkma becerileri (.77-.43, \%9,33), sözel açıklama becerileri (.81-.46, \% 8,49), kendini kontrol etme becerileri (.83-.53, \%6,36), amaç oluşturma becerileri (.73-.69, \%5,20), dinleme becerileri (.65-.42, \%4,71), görevleri tamamlama becerileri $(71-.45, \% 4,52)$ ve sonuçları kabul etme becerileri $(.58-.51, \% 4,13)$ olarak belirlenmiştir. Ölçeğin güvenirlik çalışması Cronbach Alpha İç tutarlılık, iki yarım güvenirlik katsayısı ve test tekrar-test yöntemleri ile belirlenmiştir. Faktörler ve ölçek bütünü için alfa iç tutarlılık katsayıları sırası ile $.95, .94, .92, .91, .85, .95, .87, .78, .88$ ve. 98 bulunmuştur. Faktörler ve ölçek bütünü için iki yarım güvenirlik katsayıları sırası ile $.91, .89, .85, .87, .84$, $.85, .85, .62, .82$ ve .89 bulunmuştur. Ölçeğin test-tekrar test güvenirlik katsayıları alt faktörler ve ölçek bütünü için sırasıyla şöyledir: $.98, .73, .82, .78, .83, .73, .90, .79, .60$ ve .83 'tür.

Öğretmenler tarafından doldurulan 62 maddeli ölçek beş basamakl1 "Likert Tipi" (Hiçbir Zaman, Nadiren, Ara Sıra, S1k Sık, Her Zaman) bir dereceleme ölçeği şeklinde ifade edilmiştir. Ölçekte, hiçbir zaman cevabına 1, nadiren cevabına 2, ara sıra cevabına 3, sık sık cevabına 4, her zaman cevabına 5 puan verilmektedir. Ölçekten alınabilecek en düşük puan 62 , en yüksek puan $310^{\prime}$ dur. Puanların artmas1/azalması bireylerin sosyal becerilere daha fazla sahip olduğunu/olmadığını göstermektedir (Avcıoğlu 2007).

\section{Bulgular ve Yorum}

Bulgular bölümünde gelişimi risk altında olan okul öncesi çocuklarının sosyal beceri düzeylerini belirlemesi ve bu düzeylerin aile demografik özellikleri ile ilişkisini incelemesi üzerine yapılan analizler tablolaştırılmıştır. Bağımlı-bağımsız değişkenler arasındaki ilişkinin tespiti bakımından yapılan analizlerde bağımsız ikili gruplar için t-Testi ve çoklu gruplar için One Way ANOVA (Analysis of Variance) bulgularına bakılmıştır. Bu noktada varyans eşitliklerine göre post hoc testler uygulanmıştır. Öncelikle varyansları eşit olan değerler için çoklu karşılaştırma test istatistikleri arasından en yaygın kullanılanlardan biri olan LSD (Least Significant Difference) testi uygulanmıştır.

Tablo 1. Gelişimi Risk Altında Olan Okul Öncesi Çocuklarının Sosyal Beceri Düzeylerinin Aritmetik Ortalama ve Standart Sapmaları

\begin{tabular}{|l|c|c|c|}
\hline Alt Boyutlar & n & Ortalama & $\begin{array}{c}\text { Standart } \\
\text { Sapma }\end{array}$ \\
\hline SKEB (Sonuçları Kabul Etme Becerileri) & 135 & 2,96 &, 68 \\
\hline GTB (Görevleri Tamamlama Becerileri) & 135 & 2,93 &, 66 \\
\hline DB (Dinleme Becerileri) & 135 & 2,72 &, 60 \\
\hline
\end{tabular}




\begin{tabular}{|c|c|c|c|}
\hline AOB (Amaç Oluşturma Becerileri) & 135 & 2,85 &, 63 \\
\hline KKEB (Kendini Kontrol Etme Becerileri) & 135 & 2,97 & ,68 \\
\hline SAB (Sözel Açıklama Becerileri) & 135 & 3,06 & ,61 \\
\hline ABBÇB (Akran Baskısı İle Başa Çıkma Becerileri) & 135 & 3,13 & ,69 \\
\hline $\begin{array}{l}\text { KDKEDYSB (Kızgınlık Davranışlarını Kontrol Etme ve } \\
\text { Değişikliklere Uyum Sağlama Becerileri) }\end{array}$ & 135 & 3,14 &, 62 \\
\hline KB (Kişiler Arası Beceriler) & 135 & 2,31 &, 80 \\
\hline GENEL & 135 & 2,93 & ,67 \\
\hline
\end{tabular}

Tablo 1'de ölçeğe ilişkin sayısal değerlere bağlı olarak gelişimi risk altında olan okul öncesi çocuklarının sosyal beceri düzeylerinin genel aritmetik ortalamasının $(O=2,93)$ ortalama seviyenin altında kaldığı görülmektedir. Alt boyutlar açısından değerlendirildiğinde SKEB $(O=2,96)$, GTB $(\mathrm{O}=2,93)$, DB $(\mathrm{O}=2,72)$, AOB $(\mathrm{O}=2,85)$, KKEB $(\mathrm{O}=2,97)$ boyutlarının aritmetik ortalamalarının ortalamanın altında bir düzeyde olduğu, $\mathrm{SAB}(\mathrm{O}=3,06)$, $\mathrm{ABBÇB}(\mathrm{O}=3,13)$, $\operatorname{KDKEDYSB}(\mathrm{O}=3,14)$ boyutlarının aritmetik ortalamalarının ise ortalama düzeyinde olduğu belirlenmiştir. $\mathrm{Bu}$ bulgular doğrultusunda genel olarak gelişimi risk altında olan okul öncesi çocuklarının sosyal beceri düzeylerinin düşük düzeyde olduğu görülmektedir.

Tablo 2. Gelişimi Risk Altında Olan Okul Öncesi Çocuklarının Engellilik Durumuna Göre Sosyal Beceri Düzeylerinin Aritmetik Ortalama, Standart Sapmaları ve t Testi Sonuçları

\begin{tabular}{|c|c|c|c|c|c|c|c|}
\hline Alt Boyutlar & $\begin{array}{l}\text { Engellilik } \\
\text { Durumu }\end{array}$ & $\mathbf{n}$ & Ortalama & $\begin{array}{l}\text { Standart } \\
\text { Sapma }\end{array}$ & sd & $\mathbf{t}$ & $\mathbf{p}$ \\
\hline \multirow{2}{*}{ SKEB (Sonuçları Kabul Etme Becerileri) } & Engelli & 20 & 2,31 & 67 & \multirow{2}{*}{133} & \multirow{2}{*}{3,96} & \multirow{2}{*}{, 000} \\
\hline & Engelsiz & 115 & 2,96 & 67 & & & \\
\hline \multirow{2}{*}{ GTB (Görevleri Tamamlama Becerileri) } & Engelli & 20 & 2,18 & 97 & \multirow{2}{*}{133} & \multirow{2}{*}{4,95} & \multirow{2}{*}{, 000} \\
\hline & Engelsiz & 115 & 3,30 & ,92 & & & \\
\hline \multirow{2}{*}{ DB (Dinleme Becerileri) } & Engelli & 20 & 2,36 & 65 & \multirow{2}{*}{133} & \multirow{2}{*}{5,28} & \multirow{2}{*}{000} \\
\hline & Engelsiz & 115 & 3,27 & ,72 & & & \\
\hline \multirow{2}{*}{ AOB (Amaç Oluşturma Becerileri) } & Engelli & 20 & 1,98 & ,82 & \multirow{2}{*}{133} & \multirow{2}{*}{5,25} & \multirow{2}{*}{, 000} \\
\hline & Engelsiz & 115 & 3,24 & ,96 & & & \\
\hline \multirow{2}{*}{$\begin{array}{l}\text { KKEB (Kendini Kontrol Etme } \\
\text { Becerileri) }\end{array}$} & Engelli & 20 & 2,36 & ,96 & \multirow{2}{*}{133} & \multirow{2}{*}{3,46} & \multirow{2}{*}{, 001} \\
\hline & Engelsiz & 115 & 3,07 & ,83 & & & \\
\hline \multirow{2}{*}{ SAB (Sözel Açıklama Becerileri) } & Engelli & 20 & 1,94 & ,75 & \multirow{2}{*}{133} & \multirow{2}{*}{4,84} & \multirow{2}{*}{, 000} \\
\hline & Engelsiz & 115 & 3,00 & ,92 & & & \\
\hline \multirow{2}{*}{$\begin{array}{l}\text { ABBÇB (Akran Baskısı İle Başa Çıkma } \\
\text { Becerileri) }\end{array}$} & Engelli & 20 & 2,43 &, 80 & \multirow{2}{*}{133} & \multirow{2}{*}{2,98} & \multirow{2}{*}{, 038} \\
\hline & Engelsiz & 115 & 2,76 & ,62 & & & \\
\hline \multirow{2}{*}{$\begin{array}{l}\text { KDKEDYSB (Kızgınlık Davranışlarını } \\
\text { Kontrol Etme ve Değişikliklere Uyum } \\
\text { Sağlama Becerileri) }\end{array}$} & Engelli & 20 & 2,48 & ,68 & \multirow[b]{2}{*}{133} & \multirow[b]{2}{*}{3,29} & \multirow[b]{2}{*}{,002 } \\
\hline & Engelsiz & 115 & 3,01 & ,66 & & & \\
\hline \multirow{2}{*}{ KB (Kişiler Arası Beceriler) } & Engelli & 20 & 2,55 &, 77 & \multirow{2}{*}{133} & \multirow{2}{*}{2,64} & 009 \\
\hline & Engelsiz & 115 & 3,03 &, 74 & & & , 009 \\
\hline & Engelli & 20 & 2,36 &, 61 & & & \\
\hline GENEL & Engelsiz & 115 & 3,02 &, 61 & 133 & 4,43 & 年, \\
\hline
\end{tabular}

Tablo 2'de yer alan bulgular incelendiğinde SKEB alt boyutunda gelişimi risk altında olan engelsiz çocukların aritmetik ortalamalarının $(\mathrm{O}=2,96)$, engelli çocukların aritmetik ortalamala- 
rına $(\mathrm{O}=2,31)$ göre aritmetik ortalamalarının daha yüksek olduğu GTB alt boyutunda engelsiz çocukların aritmetik ortalamalarının $(\mathrm{O}=3,30)$, engelli çocukların ortalamalarına $(\mathrm{O}=2,18)$ göre daha yüksek olduğu, DB alt boyutunda engelsiz çocukların aritmetik ortalamalarının $(O=3,27)$, engelli çocukların aritmetik ortalamalarına $(\mathrm{O}=2,36)$ göre daha yüksek olduğu, AOB alt boyutunda engelsiz çocukların aritmetik ortalamalarının $(\mathrm{O}=3,24)$, engelli çocukların aritmetik ortalamalarına $(\mathrm{O}=1,98)$ göre daha yüksek olduğu, KKEB alt boyutunda engelsiz çocukların aritmetik ortalamalarının $(\mathrm{O}=3,07)$, engelli çocukların aritmetik ortalamalarına $(\mathrm{O}=2,36)$ göre daha yüksek olduğu, $S A B$ alt boyutunda engelsiz çocukların aritmetik ortalamalarının $(O=3,00)$, engelli çocukların aritmetik ortalamalarına $(\mathrm{O}=1,94)$ göre daha yüksek olduğu, $A B B C ̧ B$ alt boyutunda engelsiz çocukların aritmetik ortalamalarının $(\mathrm{O}=2,76)$, engelli çocukların aritmetik ortalamalarına $(\mathrm{O}=2,43)$ göre daha yüksek olduğu, KDKEDYSB alt boyutunda engelsiz çocukların aritmetik ortalamalarının $(\mathrm{O}=3,01)$, engelli çocukların aritmetik ortalamalarına $(\mathrm{O}=2,48)$ göre daha yüksek olduğu, $\mathrm{KB}$ alt boyutunda engelsiz çocukların aritmetik ortalamalarının $(\mathrm{O}=3,03)$, engelli çocukların aritmetik ortalamalarına $(\mathrm{O}=2,55)$ göre daha yüksek olduğu ve genel ortalamada da engelsiz çocukların aritmetik ortalamalarının $(\mathrm{O}=3,02)$, engelli çocukların aritmetik ortalamalarına $(\mathrm{O}=2,26)$ göre daha yüksek olduğu görülmektedir.

Gelişimi risk altında olan engelli ve engelsiz okul öncesi çocuklarının sosyal beceri düzeylerinin aritmetik ortalamaları arasındaki farkın anlamlı olup olmadığını ortaya koymak amacıyla yapılan $t$ Testi sonuçlarına göre SKEB alt boyutunda, $\mathrm{t}(133)=3,96 ; \mathrm{p}<0.05$, GTB alt boyutunda, $\mathrm{t}(133)=4,95 ; \mathrm{p}<0.05$, DB, $\mathrm{t}(133)=5,28 ; \mathrm{p}<0.05$, AOB alt boyutunda, $\mathrm{t}(133)=5,25 ; \mathrm{p}<$ 0.05 , KKEB alt boyutunda $\mathrm{t}(133)=3,46 ; \mathrm{p}=0.01$, SAB alt boyutunda, $\mathrm{t}(133)=4,84 ; \mathrm{p}<0.05$, KDKEDYSB alt boyutunda, $\mathrm{t}(133)=3,29 ; \mathrm{p}=0.02$, KB alt boyutunda, $\mathrm{t}(133)=2,64 ; \mathrm{p}=0.09$ ve genel ortalamaya $\mathrm{t}(133)=4,43 ; \mathrm{p}<0.05$ göre iki grup arasındaki fark önemli çıkmıştır. ABBÇB alt boyutunda ise $\mathrm{t}(133)=2,98$ farkın anlamlı olmadığı bulunmuştur. Sonuç olarak gelişimi risk altında olan engelsiz çocukların sosyal beceri düzeyleri genelde ve tüm alt boyutlarda engelli olanlara göre daha yüksek olduğu belirlenmiştir.

Tablo 3. Gelişimi Risk Altında Olan Okul Öncesi Çocuklarının Anne Öğrenim Durumuna Göre Sosyal Beceri Düzeylerinin Aritmetik Ortalama, Standart Sapmaları ve t Testi Sonuçları

\begin{tabular}{|c|c|c|c|c|c|c|c|}
\hline Alt Boyutlar & $\begin{array}{l}\text { Anne Öğrenim } \\
\text { Durumu }\end{array}$ & $\mathbf{n}$ & Ortalama & $\begin{array}{l}\text { Standart } \\
\text { Sapma }\end{array}$ & sd & t & $\mathbf{p}$ \\
\hline SKEB (Sonuçları Kabul Etme & İlkokul ve Ortaokul & 80 & 2,73 &, 62 & \multirow{2}{*}{133} & \multirow{2}{*}{2,65} & \multirow{2}{*}{009} \\
\hline Becerileri) & Lise ve Üzeri & 55 & 3,05 & ,79 & & & \\
\hline GTB (Görevleri Tamamlama & İlkokul ve Ortaokul & 80 & 3,01 &, 86 & \multirow{2}{*}{133} & \multirow{2}{*}{, 52} & \multirow{2}{*}{,599 } \\
\hline Becerileri) & Lise ve Üzeri & 55 & 3,19 & 1,20 & & & \\
\hline \multirow{2}{*}{ DB (Dinleme Becerileri) } & İlkokul ve Ortaokul & 80 & 3,11 & 65 & \multirow{2}{*}{133} & \multirow{2}{*}{,47 } & \multirow{2}{*}{ 638 } \\
\hline & Lise ve Üzeri & 55 & 3,17 & ,93 & & & \\
\hline \multirow{2}{*}{ AOB (Amaç Oluşturma Becerileri) } & İlkokul ve Ortaokul & 80 & 3,06 & ,96 & \multirow{2}{*}{133} & \multirow{2}{*}{,66 } & \multirow{2}{*}{ 947 } \\
\hline & Lise ve Üzeri & 55 & 3,05 & 1,16 & & & \\
\hline KKEB (Kendini Kontrol Etme & İlkokul ve Ortaokul & 80 & 2,81 &, 81 & \multirow{2}{*}{133} & \multirow{2}{*}{2,46} & \multirow{2}{*}{, 015} \\
\hline Becerileri) & Lise ve Üzeri & 55 & 3,19 & ,94 & & & \\
\hline \multirow{2}{*}{ SAB (Sözel Açılklama Becerileri) } & İlkokul ve Ortaokul & 80 & 2,73 &, 85 & \multirow{2}{*}{133} & \multirow{2}{*}{1,58} & \multirow{2}{*}{, 115} \\
\hline & Lise ve Üzeri & 55 & 3,00 & 1,11 & & & \\
\hline $111 \mathrm{Ba}$ & Illkokul ve Ortaokul & 80 & 2,62 & ,54 & \multirow{2}{*}{133} & \multirow{2}{*}{1,92} & \multirow{2}{*}{, 056} \\
\hline Çıkma & Lise ve Üzeri & 55 & 2,85 & ,79 & & & \\
\hline KDKEDYSB (Kızgınlık Davranış- & İlkokul ve Ortaokul & 80 & 2,85 & ,62 & 133 & 1,53 & , 123 \\
\hline
\end{tabular}




\begin{tabular}{|c|c|c|c|c|c|c|c|}
\hline $\begin{array}{l}\text { larını Kontrol Etme ve Değişiklik- } \\
\text { lere Uyum Sağlama Becerileri) }\end{array}$ & Lise ve Üzeri & 55 & 3,04 & ,77 & & & \\
\hline \multirow{2}{*}{ KB (Kişiler Arası Beceriler) } & İlkokul ve Ortaokul & 80 & 2,84 & ,68 & \multirow{2}{*}{133} & \multirow{2}{*}{2,15} & \multirow{2}{*}{, 003} \\
\hline & Lise ve Üzeri & 55 & 3,12 &, 84 & & & \\
\hline \multirow{2}{*}{ GENEL } & İlkokul ve Ortaokul & 80 & 2,84 &, 55 & \multirow{2}{*}{133} & \multirow{2}{*}{1,96} & \multirow{2}{*}{, 052} \\
\hline & Lise ve Üzeri & 55 & 3,05 & ,76 & & & \\
\hline
\end{tabular}

Tablo 3'de yer alan bulgular incelendiğinde SKEB alt boyutunda anne öğrenim düzeyi lise ve üzeri öğrenim durumu olan gelişimi risk altındaki çocukların aritmetik ortalamalarının $(\mathrm{O}=3,05)$, ilkokul ve ortaokul öğrenim durumu olanların aritmetik ortalamalarına $(\mathrm{O}=2,73)$ göre daha yüksek olduğu, KKEB alt boyutunda anne öğrenim düzeyi lise ve üzeri öğrenim durumu olanların aritmetik ortalamalarının $(\mathrm{O}=3,19)$, ilkokul ve ortaokul öğrenim durumu olanların aritmetik ortalamalarına $(\mathrm{O}=2,81)$ göre daha yüksek olduğu, $\mathrm{KB}$ alt boyutunda anne öğrenim düzeyi lise ve üzeri öğrenim durumu olanların aritmetik ortalamalarının $(\mathrm{O}=3,12)$, ilkokul ve ortaokul öğrenim durumu olanların aritmetik ortalamalarına $(O=2,84)$ göre daha yüksek olduğu görülmektedir. GTB, DB, AOB, SAB, ABBÇB, KDKEDYSB alt boyutlarında anne öğrenim düzeyi lise ve üzeri öğrenim durumu olanlar ile ilkokul ve ortaokul öğrenim durumunda olanların aritmetik ortalamalarının birbirine yakın olduğu görülmektedir.

Gelişimi risk altında olan anne öğrenim durumu lise ve üzeri ile ilkokul ve ortaokul olan okul öncesi çocuklarının sosyal beceri düzeylerinin aritmetik ortalamaları arasındaki farkın anlamlı olup olmadığını ortaya koymak amacıyla yapılan $t$ Testi sonuçlarına göre SKEB alt boyutunda $\mathrm{t}(133)=2,65 ; \mathrm{p}<0.05$, KKEB alt boyutunda $\mathrm{t}(133)=2,46 ; \mathrm{p}=0.01$, KB alt boyutunda $\mathrm{t}(133)=2,15 ; \mathrm{p}=0.03$ iki grup arasındaki fark önemli çıkmıştır. GTB, DB, AOB, SAB, $\mathrm{ABBÇB}, \mathrm{KDKEDYSB}$ alt boyutlarında, lise ve üzeri öğrenim durumu olanlar ile ilkokul ve ortaokul öğrenim durumunda olan annelerin çocuklarının sosyal beceri aritmetik ortalamaları arasındaki farkın önemsiz olduğu saptanmıştır. Genel aritmetik ortalamaya göre de her iki grup arasındaki farkın önemsiz olduğu belirlenmiştir. Sonuç olarak gelişimi risk altında olan ve anne öğrenim durumu lise ve üzeri olan çocukların sosyal beceri düzeyleri bazı alt boyutlarda anne öğrenim durumu ilkokul ve ortaokul olanlara göre daha yüksektir.

Tablo 4. Gelişimi Risk Altında Olan Okul Öncesi Çocuklarının Baba Öğrenim Durumuna Göre Sosyal Beceri Düzeylerinin Aritmetik Ortalama, Standart Sapmaları

\begin{tabular}{|l|c|c|c|c|}
\hline \multirow{2}{*}{ Alt Boyutlar } & $\begin{array}{c}\text { Baba Öğrenim } \\
\text { Durumu }\end{array}$ & $\mathbf{n}$ & Ortalama & $\begin{array}{c}\text { Standart } \\
\text { Sapma }\end{array}$ \\
\hline \multirow{3}{*}{ SKEB (Sonuçları Kabul Etme Becerileri) } & İlkokul & 59 & 2,80 &, 64 \\
\cline { 2 - 5 } & Ortaokul & 31 & 2,77 &, 70 \\
\cline { 2 - 5 } & Lise ve üzeri & 45 & 3,01 &, 79 \\
\hline \multirow{3}{*}{ GTB (Görevleri Tamamlama Becerileri) } & İlkokul & 59 & 3,19 &, 89 \\
\cline { 2 - 5 } & Ortaokul & 31 & 3,23 & 1,02 \\
\cline { 2 - 5 } & Lise ve üzeri & 45 & 2,99 & 1,15 \\
\hline \multirow{3}{*}{ DB (Dinleme Becerileri) } & İlkokul & 59 & 3,05 &, 70 \\
\cline { 2 - 5 } & Ortaokul & 31 & 3,11 &, 57 \\
\cline { 2 - 5 } & Lise ve üzeri & 45 & 3,25 &, 97 \\
\hline \multirow{3}{*}{ AOB (Amaç Oluşturma Becerileri) } & İlkokul & 59 & 3,01 &, 97 \\
\cline { 2 - 5 } & Ortaokul & 31 & 2,93 &, 93 \\
\cline { 2 - 5 } & Lise ve üzeri & 45 & 3,21 & 1,19 \\
\hline \multirow{2}{*}{ KKEB (Kendini Kontrol Etme Becerileri) } & İlkokul & 59 & 2,90 &, 79 \\
\cline { 2 - 5 } & Ortaokul & 31 & 3,00 &, 88 \\
\hline
\end{tabular}




\begin{tabular}{|l|c|c|c|c|}
\hline \multirow{3}{*}{ SAB (Sözel Açıklama Becerileri) } & Lise ve üzeri & 45 & 3,04 & 1,00 \\
\hline \multirow{3}{*}{ ABBÇB (Akran Baskısı İle Başa Çıkma Becerileri) } & İlkokul & 59 & 2,67 &, 87 \\
\cline { 2 - 4 } & Ortaokul & 31 & 2,68 &, 83 \\
\cline { 2 - 4 } & Lise ve üzeri & 45 & 3,18 & 1,10 \\
\hline \multirow{2}{*}{ KDKEDYSB (Kızgınlık Davranışlarını Kontrol Etme } & İlkokul & 59 & 2,58 &, 50 \\
\cline { 2 - 4 } ve Değişikliklere Uyum Sağlama Becerileri) & Ortaokul & 31 & 2,71 &, 58 \\
\cline { 2 - 4 } & Lise ve üzeri & 45 & 2,90 &, 84 \\
\hline \multirow{3}{*}{ KB (Kişiler Arası Beceriler) } & İlkokul & 59 & 2,87 &, 66 \\
\cline { 2 - 4 } & Ortaokul & 31 & 2,92 &, 54 \\
\cline { 2 - 4 } & Lise ve üzeri & 45 & 3,00 &, 81 \\
\hline \multirow{3}{*}{ GENEL } & İlkokul & 59 & 2,82 &, 65 \\
\cline { 2 - 5 } & Ortaokul & 31 & 2,98 &, 60 \\
\cline { 2 - 5 } & Lise ve üzeri & 45 & 3,13 &, 95 \\
\hline & İlkokul & 59 & 2,82 &, 55 \\
\cline { 2 - 5 } & Ortaokul & 31 & 2,90 &, 52 \\
\cline { 2 - 5 } & Lise ve üzeri & 45 & 3,07 &, 65 \\
\hline
\end{tabular}

Tablo 4'de yer alan bulgular incelendiğinde SAB alt boyutunda baba öğrenim düzeyi lise ve üzeri öğrenim durumu olan gelişimi risk altında olan çocukların aritmetik ortalamalarının $(\mathrm{O}=3,18)$, ilkokul $(\mathrm{O}=2,67)$ ve ortaokul öğrenim durumu olanların aritmetik ortalamalarına $(\mathrm{O}=2,68)$ göre daha yüksek olduğu, SKEB alt boyutunda baba öğrenim düzeyi lise ve üzeri öğrenim durumu olan çocukların sosyal beceri aritmetik ortalamaları $(\mathrm{O}=3,01)$ ile ilkokul $(\mathrm{O}=2,80)$ ve ortaokul öğrenim durumu olanların aritmetik ortalamaları $(\mathrm{O}=2,77)$ arasında az fark olduğu, GTB alt boyutunda baba öğrenim düzeyi lise ve üzeri öğrenim durumu olanların aritmetik ortalamaları $(\mathrm{O}=2,99)$ ile ilkokul $(\mathrm{O}=3,19)$ ve ortaokul öğrenim durumu olanların aritmetik ortalamaları $(\mathrm{O}=3,23)$ az fark olduğu, $\mathrm{DB}$ alt boyutunda baba öğrenim düzeyi lise ve üzeri öğrenim durumu olanların aritmetik ortalamalarının $(\mathrm{O}=3,25)$ ile ilkokul $(\mathrm{O}=3,05)$ ve ortaokul öğrenim durumu olanların aritmetik ortalamalarının $(\mathrm{O}=3,11)$ birbirine yakın olduğu, AOB alt boyutunda baba öğrenim düzeyi lise ve üzeri öğrenim durumu olanların aritmetik ortalamaları $(\mathrm{O}=3,21)$ ile ilkokul $(\mathrm{O}=3,01)$ ve ortaokul öğrenim durumu olanların aritmetik ortalamaları $(\mathrm{O}=2,93)$ arasında az fark olduğu, KKEB alt boyutunda baba öğrenim düzeyi lise ve üzeri öğrenim durumu olanların aritmetik ortalamaları $(O=3,04)$ ile ilkokul $(O=2,90)$ ve ortaokul öğrenim durumu olanların aritmetik ortalamaları $(\mathrm{O}=3,00)$ arasında az fark olduğu, $\mathrm{ABBÇB}$ alt boyutunda baba öğrenim düzeyi lise ve üzeri öğrenim durumu olanların aritmetik ortalamalarının $(\mathrm{O}=2,90)$ ile ilkokul $(\mathrm{O}=2,58)$ ve ortaokul öğrenim durumu olanların aritmetik ortalamalarının $(\mathrm{O}=2,71)$ birbirine yakın olduğu, KDKEDYSB alt boyutunda baba öğrenim düzeyi lise ve üzeri öğrenim durumu olanların aritmetik ortalamaları $(O=3,00)$ ile ilkokul $(\mathrm{O}=2,87)$ ve ortaokul öğrenim durumu olanların aritmetik ortalamaları $(\mathrm{O}=2,92)$ arasında az fark olduğu, KB alt boyutunda lise ve üzeri öğrenim durumu olanların aritmetik ortalamaları $(\mathrm{O}=3,13)$ ile ilkokul $(\mathrm{O}=2,82)$ ve ortaokul ögrenim durumu olanların aritmetik ortalamaları $(\mathrm{O}=2,98)$ arasında az fark olduğu ve genel ortalamada baba öğrenim düzeyi lise ve üzeri öğrenim durumu olanların aritmetik ortalamaları $(\mathrm{O}=3,07)$ ile ilkokul $(\mathrm{O}=2,82)$ ve ortaokul öğrenim durumu olanların aritmetik ortalamaları $(\mathrm{O}=2,90)$ arasında az fark olduğu görülmektedir.

Gelişimi risk altında olan baba öğrenim durumu lise ve üzeri ile ilkokul ve ortaokul olan okul öncesi çocuklarının sosyal beceri düzeylerinin aritmetik ortalamaları arasındaki farkın anlamlı olup olmadığını ortaya koymak amacıyla ANOVA analizi yapılmıştır. ANOVA analizinden önce 
varyansların homojenliği testi yapılmış ve varyansların homojen olduğu belirlenmiştir.

Tablo 5. Gelişimi Risk Altında Olan Okul Öncesi Çocuklarının Baba Öğrenim Durumuna Göre Sosyal Beceri Düzeylerinin ANOVA Sonuçları

\begin{tabular}{|c|c|c|c|c|c|c|c|}
\hline Alt Boyutlar & $\begin{array}{c}\text { Varyansın } \\
\text { Kaynağı }\end{array}$ & $\begin{array}{l}\text { Kareler } \\
\text { Toplamı }\end{array}$ & sd & $\begin{array}{c}\text { Kareler } \\
\text { Ortalaması }\end{array}$ & $\mathbf{F}$ & $\mathbf{p}$ & $\begin{array}{c}\text { Önem } \\
\text { Denetimi }\end{array}$ \\
\hline \multirow{3}{*}{$\begin{array}{l}\text { SKEB (Sonuçlar1 } \\
\text { Kabul Etme } \\
\text { Becerileri) }\end{array}$} & Gruplararası & 1,428 & 2 & \multirow{3}{*}{$\begin{array}{l}, 714 \\
, 506\end{array}$} & \multirow{3}{*}{1,411} & \multirow{3}{*}{,248 } & \multirow{3}{*}{$\begin{array}{c}\text { Fark } \\
\text { Önemsiz }\end{array}$} \\
\hline & Gruplariçi & 66,797 & 133 & & & & \\
\hline & Toplam & 68,225 & 135 & & & & \\
\hline \multirow{3}{*}{$\begin{array}{l}\text { GTB (Görevleri } \\
\text { Tamamlama } \\
\text { Becerileri) }\end{array}$} & Gruplararas1 & 1,463 & 2 & \multirow{3}{*}{$\begin{array}{l}, 732 \\
1,033\end{array}$} & \multirow{3}{*}{,708 } & \multirow{3}{*}{,495 } & \multirow{3}{*}{$\begin{array}{c}\text { Fark } \\
\text { Önemsiz }\end{array}$} \\
\hline & Gruplariçi & 136,400 & 133 & & & & \\
\hline & Toplam & 137,863 & 135 & & & & \\
\hline \multirow{3}{*}{$\begin{array}{l}\text { DB (Dinleme } \\
\text { Becerileri) }\end{array}$} & Gruplararas1 & ,994 & 2 & \multirow{3}{*}{$\begin{array}{l}, 497 \\
, 610\end{array}$} & \multirow{3}{*}{,814 } & \multirow{3}{*}{,445 } & \multirow{3}{*}{$\begin{array}{c}\text { Fark } \\
\text { Önemsiz }\end{array}$} \\
\hline & Gruplariçi & 80,578 & 133 & & & & \\
\hline & Toplam & 81,572 & 135 & & & & \\
\hline \multirow{3}{*}{$\begin{array}{l}\text { AOB (Amaç } \\
\text { Oluşturma } \\
\text { Becerileri) }\end{array}$} & Gruplararas1 & 1,699 & 2 & \multirow{3}{*}{$\begin{array}{l}, 849 \\
1,095\end{array}$} & \multirow{3}{*}{, 776} & \multirow{3}{*}{,463 } & \multirow{3}{*}{$\begin{array}{c}\text { Fark } \\
\text { Önemsiz }\end{array}$} \\
\hline & Gruplariçi & 144,565 & 133 & & & & \\
\hline & Toplam & 146,263 & 135 & & & & \\
\hline \multirow{3}{*}{$\begin{array}{l}\text { KKEB (Kendini } \\
\text { Kontrol Etme } \\
\text { Becerileri) }\end{array}$} & Gruplararası &, 554 & 2 & \multirow{3}{*}{$\begin{array}{l}, 273 \\
, 796\end{array}$} & \multirow{3}{*}{, 343} & \multirow{3}{*}{,711 } & \multirow{3}{*}{$\begin{array}{c}\text { Fark } \\
\text { Önemsiz }\end{array}$} \\
\hline & Gruplariçi & 105,038 & 133 & & & & \\
\hline & Toplam & 105,583 & 135 & & & & \\
\hline \multirow{3}{*}{$\begin{array}{l}\text { SAB (Sözel } \\
\text { Açıklama } \\
\text { Becerileri) }\end{array}$} & Gruplararası & 7,888 & 2 & \multirow{3}{*}{$\begin{array}{c}3,944 \\
, 905\end{array}$} & \multirow{3}{*}{4,357} & \multirow{3}{*}{, 015} & \multirow{3}{*}{$\begin{array}{c}\text { Fark Önemli } \\
1-3\end{array}$} \\
\hline & Gruplariçi & 119,501 & 133 & & & & \\
\hline & Toplam & 127,390 & 135 & & & & \\
\hline ABBÇB (Akran & Gruplararası & 2,229 & 2 & & & & \\
\hline Baskısı İle Başa & Gruplariçi & 56,581 & 133 & $\begin{array}{l}1,314 \\
420\end{array}$ & 3,066 & ,050 & $\begin{array}{l}\text { Fark } \\
\text { Önemsiz }\end{array}$ \\
\hline Çıkma Becerileri) & Toplam & 59,210 & 135 & & & & \\
\hline KDKEDYSB & Gruplararas1 &, 431 & 2 & & & & \\
\hline (Kızgınlık & Gruplariçi & 64,102 & 133 & & & & \\
\hline $\begin{array}{l}\text { Davranışlarını } \\
\text { Kontrol Etme ve } \\
\text { Değişikliklere } \\
\text { Uyum Sağlama } \\
\text { Becerileri) }\end{array}$ & Toplam & 64,532 & 135 & $\begin{array}{l}, 215 \\
, 486\end{array}$ & ,443 & ,643 & $\begin{array}{c}\text { Fark } \\
\text { Önemsiz }\end{array}$ \\
\hline KB (Kisiler Aras & Gruplararası & 2,433 & 2 & & & & Fark \\
\hline Beceriler) & Gruplariçi & 75,642 & 133 & $\begin{array}{l}1,210 \\
.573\end{array}$ & 2,123 & ,124 & Önemsiz \\
\hline & Toplam & 78,075 & 135 & & & & \\
\hline & Gruplararası & 1,561 & 2 & & & & \\
\hline GENEL & Gruplariçi & 55,967 & 133 & $\begin{array}{l}1 / 81 \\
424\end{array}$ & 1,841 & 163 & Önemsiz \\
\hline & Toplam & 57,528 & 135 & & & & \\
\hline
\end{tabular}

Tablo 5'de yer alan bulgular incelendiğinde gelişimi risk altında olan okul öncesi çocuklarının baba öğrenim durumuna göre sosyal beceri düzeylerinin ANOVA sonuçlarında SAB alt boyutunda anlamlı bir fark olduğu $\mathrm{F}(3,07)=4,357, \mathrm{p}<0.05$ görülmektedir. SAB alt boyutu dişında tüm alt boyutlarda ve genelde anlamlı bir farkın olmadığ saptanmıştır. SAB alt boyutunda farkın kaynağını bulmak için Scheffe testi yapılmıştır. Scheffe testi sonucuna göre 3 düzeyinde $(\mathrm{O}=3,18)$ öğrenim durumunda olanların 1 düzeyinde $(\mathrm{O}=2,67)$ öğrenim durumunda olanlara göre çocuklarının sosyal beceri düzeyinin $\mathrm{SAB}$ alt boyutunda daha yüksek olduğu belirlen- 
miştir. Scheffe testi sonucuna göre 1 ile 3 arasında diğer bir deyişle ilkokul öğrenim durumu ile lise ve üzeri öğrenim durumu arasında fark bulunduğu saptanmıştır.

Tablo 6. Gelişimi Risk Altında Olan Okul Öncesi Çocuklarının Daha Önceki Okul Öncesi Eğitim Durumuna Göre Sosyal Beceri Düzeylerinin Aritmetik Ortalama ve Standart Sapmaları

\begin{tabular}{|c|c|c|c|c|}
\hline Alt Boyutlar & $\begin{array}{c}\text { Daha Önceki Okul Öncesi } \\
\text { Eğitim Alma Durumu }\end{array}$ & $\mathbf{n}$ & Ortalama & $\begin{array}{l}\text { Standart } \\
\text { Sapma }\end{array}$ \\
\hline \multirow{2}{*}{ SKEB (Sonuçları Kabul Etme Becerileri) } & Almış & 27 & 3,12 & ,99 \\
\hline & Almamış & 108 & 2,80 & ,61 \\
\hline \multirow{2}{*}{ GTB (Görevleri Tamamlama Becerileri) } & Almış & 27 & 3,23 & 1,29 \\
\hline & Almamış & 108 & 3,11 & ,93 \\
\hline \multirow{2}{*}{ DB (Dinleme Becerileri) } & Almış & 27 & 3,57 & 97 \\
\hline & Almamış & 108 & 3,02 & ,68 \\
\hline \multirow{2}{*}{ AOB (Amaç Oluşturma Becerileri) } & Almış & 27 & 3,75 & 1,26 \\
\hline & Almamış & 108 & 2,88 & ,90 \\
\hline \multirow{2}{*}{ KKEB (Kendini Kontrol Etme Becerileri) } & Almış & 27 & 3,17 & 1,21 \\
\hline & Almamış & 108 & 2,92 & ,78 \\
\hline \multirow{2}{*}{ SAB (Sözel Açıklama Becerileri) } & Almış & 27 & 3,56 & 1,11 \\
\hline & Almamış & 108 & 2,66 &, 85 \\
\hline \multirow{2}{*}{$\begin{array}{l}\text { ABBÇB (Akran Baskısı İle Başa Çıkma } \\
\text { Becerileri) }\end{array}$} & Almış & 27 & 3,07 & ,94 \\
\hline & Almamış & 108 & 2,63 & ,54 \\
\hline \multirow{2}{*}{$\begin{array}{l}\text { KDKEDYSB (Kızgınlık Davranışlarını } \\
\text { Kontrol Etme ve Değişikliklere Uyum } \\
\text { Sağlama Becerileri) }\end{array}$} & Almış & 27 & 3,43 & 81 \\
\hline & Almamış & 108 & 2,80 & 60 \\
\hline \multirow{2}{*}{ KB (Kişiler Arası Beceriler) } & Almış & 27 & 3,35 & 1,02 \\
\hline & Almamış & 108 & 2,86 & ,65 \\
\hline \multirow{2}{*}{ GENEL } & Almış & 27 & 3,34 & 92 \\
\hline & Almamış & 108 & 2,82 &, 52 \\
\hline
\end{tabular}

Tablo 6'da yer alan bulgular incelendiğinde gelişimi risk altında olan çocukların DB alt boyutunda daha önce okul öncesi eğitimi almış olanların sosyal beceri aritmetik ortalamalarının $(\mathrm{O}=3,57)$ okul öncesi eğitim almamış olanların aritmetik ortalamalarına $(\mathrm{O}=3,02)$ göre daha yüksek olduğu görülmektedir. AOB alt boyutunda daha önce okul öncesi eğitimi almış çocukların aritmetik ortalamalarının $(\mathrm{O}=3,75)$ okul öncesi eğitim almamış çocukların aritmetik ortalamalarına $(\mathrm{O}=2,88)$ göre daha yüksek olduğu görülmektedir. $\mathrm{SAB}$ alt boyutunda daha önce okul öncesi eğitimi almış çocukların sosyal beceri aritmetik ortalamalarının $(O=3,56)$ okul öncesi eğitim almamış çocukların aritmetik ortalamalarına $(\mathrm{O}=2,66)$ göre daha yüksek olduğu görülmektedir. $\mathrm{ABBÇB}$ alt boyutunda daha önce okul öncesi eğitimi almış çocukların sosyal beceri aritmetik ortalamalarının $(\mathrm{O}=3,07)$ okul öncesi eğitim almamış çocukların aritmetik ortalamalarına $(\mathrm{O}=2,63)$ göre daha yüksek olduğu görülmektedir. KDKEDYSB alt boyutunda daha önce okul öncesi eğitimi almış çocukların sosyal beceri aritmetik ortalamalarının $(O=3,43)$ okul öncesi eğitim almamış çocukların aritmetik ortalamalarına $(O=2,80)$ göre daha yüksek olduğu görülmektedir. KB alt boyutunda daha önce okul öncesi eğitimi almış çocukların sosyal beceri aritmetik ortalamalarının $(\mathrm{O}=3,35)$ okul öncesi eğitim almamış çocukların aritmetik ortalamalarına $(\mathrm{O}=2,86)$ göre daha yüksek olduğu ve genel ortalamada da okul öncesi eğitimi almış çocukların sosyal beceri aritmetik ortalamalarının $(\mathrm{O}=3,34)$ okul öncesi eğitim almamış çocukların aritmetik ortalamalarına $(\mathrm{O}=2,82)$ göre daha yüksek olduğu görülmektedir. SKEB alt boyutunda gelişimi risk altında olan çocuklardan daha önce okul öncesi eğitimi almış olanların 
aritmetik ortalamalarıyla $(\mathrm{O}=3,12)$ okul öncesi eğitim almamış olanların aritmetik ortalamalarının $(\mathrm{O}=2,80)$ birbirine yakın olduğu görülmektedir. GTB alt boyutunda daha önce okul öncesi eğitimi almış çocukların aritmetik ortalamalarıyla $(\mathrm{O}=3,23)$ okul öncesi eğitim almamış çocukların aritmetik ortalamalarının $(\mathrm{O}=3,11)$ birbirine yakın olduğu görülmektedir. KKEB alt boyutunda daha önce okul öncesi eğitimi almış çocukların sosyal beceri aritmetik ortalamalarıyla $(\mathrm{O}=3,17)$ okul öncesi eğitim almamış çocukların aritmetik ortalamalarının $(\mathrm{O}=2,92)$ birbirine yakın olduğu görülmektedir.

Gelişimi risk altında olan daha önce okul öncesi eğitim almış ve almamış okul öncesi çocuklarının sosyal beceri düzeylerinin aritmetik ortalamaları arasındaki farkın anlamlı olup olmadığını ortaya koymak amacıyla yapılan Mann Whitney U Testi sonuçları Tablo 7'de yer almaktadır.

Tablo 7. Gelişimi Risk Altında Olan Okul Öncesi Çocuklarının Daha Önceki Okul Öncesi Eğitim Durumuna Göre Sosyal Beceri Düzeylerinin Mann Whitney U Testi Sonuçları

\begin{tabular}{|c|c|c|c|c|c|c|c|}
\hline Alt Boyutlar & $\begin{array}{l}\text { Daha Önce } \\
\text { Okul Öncesi } \\
\text { Eğitim Alma } \\
\text { Durumu }\end{array}$ & $\mathbf{n}$ & $\begin{array}{c}\text { Sira } \\
\text { Ortalaması }\end{array}$ & $\begin{array}{c}\text { Sira } \\
\text { Toplamı }\end{array}$ & $\mathbf{U}$ & $\mathbf{p}$ & $\begin{array}{c}\text { Önem } \\
\text { Denetimi }\end{array}$ \\
\hline \multirow{2}{*}{$\begin{array}{l}\text { SKEB (Sonuçları } \\
\text { Kabul Etme } \\
\text { Becerileri) }\end{array}$} & Almış & 27 & 76,19 & 2057,00 & \multirow{2}{*}{1237,00} & \multirow{2}{*}{,213 } & \multirow{2}{*}{$\begin{array}{c}\text { Fark } \\
\text { Önemsiz }\end{array}$} \\
\hline & Almamış & 108 & 65,95 & 7123,00 & & & \\
\hline \multirow{2}{*}{$\begin{array}{l}\text { GTB (Görevleri } \\
\text { Tamamlama } \\
\text { Becerileri) }\end{array}$} & Almış & 27 & 70,76 & 1916,50 & \multirow{2}{*}{1383,50} & \multirow{2}{*}{,676 } & \multirow{2}{*}{$\begin{array}{c}\text { Fark } \\
\text { Önemsiz }\end{array}$} \\
\hline & Almamış & 108 & 67,31 & 7269,50 & & & \\
\hline \multirow{2}{*}{$\begin{array}{l}\text { DB (Dinleme } \\
\text { Becerileri) }\end{array}$} & Almış & 27 & 86,94 & 2347,50 & \multirow{2}{*}{946,500} & \multirow{2}{*}{, 005} & \multirow{2}{*}{$\begin{array}{c}\text { Fark } \\
\text { Önemli }\end{array}$} \\
\hline & Almamış & 108 & 63,26 & 6834,50 & & & \\
\hline \multirow{2}{*}{$\begin{array}{l}\text { AOB (Amaç } \\
\text { Oluşturma Becerileri) }\end{array}$} & Almış & 27 & 91,37 & 2467,00 & \multirow{2}{*}{827,00} & \multirow{2}{*}{, 000} & \multirow{2}{*}{$\begin{array}{c}\text { Fark } \\
\text { Önemsiz }\end{array}$} \\
\hline & Almamış & 108 & 62,16 & 6713,00 & & & \\
\hline \multirow{2}{*}{$\begin{array}{l}\text { KKEB (Kendini } \\
\text { Kontrol Etme } \\
\text { Becerileri) }\end{array}$} & Almış & 27 & 76,24 & 2058,50 & \multirow{2}{*}{1235,00} & \multirow{2}{*}{,218 } & \multirow{2}{*}{$\begin{array}{c}\text { Fark } \\
\text { Önemli }\end{array}$} \\
\hline & Almamış & 108 & 65,94 & 7121,50 & & & \\
\hline \multirow{2}{*}{$\begin{array}{l}\text { SAB (Sözel } \\
\text { Aç1klama Becerileri) }\end{array}$} & Almış & 27 & 96,33 & 2601,00 & \multirow{2}{*}{693,00} & \multirow{2}{*}{, 000} & \multirow{2}{*}{$\begin{array}{c}\text { Fark } \\
\text { Önemli }\end{array}$} \\
\hline & Almamış & 108 & 60,92 & 6579,00 & & & \\
\hline \multirow{2}{*}{$\begin{array}{l}\text { ABBÇB (Akran } \\
\text { Baskısı İle Başa } \\
\text { Çıkma Becerileri) }\end{array}$} & Almış & 27 & 85,00 & 2295,00 & \multirow{2}{*}{999,0} & \multirow{2}{*}{, 011} & \multirow{2}{*}{$\begin{array}{c}\text { Fark } \\
\text { Önemli }\end{array}$} \\
\hline & Almamış & 108 & 63,75 & 6885,60 & & & \\
\hline \multirow{2}{*}{$\begin{array}{l}\text { KDKEDYSB } \\
\text { (Kızgınlık Davranışla- } \\
\text { rını Kontrol Etme ve } \\
\text { Değişikliklere Uyum } \\
\text { Sağlama Becerileri) }\end{array}$} & Almış & 27 & 92,04 & 2485,00 & \multirow{2}{*}{809,00} & \multirow{2}{*}{, 000} & \multirow{2}{*}{$\begin{array}{c}\text { Fark } \\
\text { Önemli }\end{array}$} \\
\hline & Almamış & 108 & 61,99 & 6695,00 & & & \\
\hline \multirow{2}{*}{$\begin{array}{l}\text { KB (Kişiler Arası } \\
\text { Beceriler) }\end{array}$} & Almış & 27 & 82,00 & 6944,00 & \multirow{2}{*}{1058,50} & \multirow{2}{*}{, 028} & Fark \\
\hline & Almamış & 108 & 63,30 & 2485,00 & & & Önemli \\
\hline GENEL & Almış & 27 & 89,20 & 2408,50 & 885.50 & 002 & Fark \\
\hline & Almamış & 108 & 62,70 & 6771,50 & & & Önemli \\
\hline
\end{tabular}

Tablo 7'de yer alan bulgular incelendiğinde gelişimi risk altında olan okul öncesi çocuklarının daha önce okul öncesi eğitim alıp almama durumuna göre sosyal beceri düzeylerinin Mann Whitney U Testi sonuçlarında DB alt boyutunda $(U=946,500, p<0.05)$, AOB alt boyutunda 
$(\mathrm{U}=827,00, \mathrm{p}<0.05), \mathrm{SAB}$ alt boyutunda $(\mathrm{U}=693,00, \mathrm{p}<0.05)$, ABBÇB alt boyutunda $(\mathrm{U}=999,00, \mathrm{p}<0.05)$, KDKEDYSB alt boyutunda $(\mathrm{U}=809,00, \mathrm{p}<0.05), \mathrm{KB}$ alt boyutunda $(\mathrm{U}=1058,00, \mathrm{p}<0.05)$ ve genelde $(\mathrm{U}=885,50, \mathrm{p}<0.05)$ gelişimi risk altında olan okul öncesi çocuklarının daha önce okul öncesi eğitim alıp almama durumuna göre anlamlı bir fark olduğu görülmektedir. $\mathrm{Bu}$ alt boyutlarda ve genelde sıra ortalamaları dikkate alındığında daha önce okul öncesi eğitim almış gelişimi risk altında olan çocukların sosyal becerilerinin daha önce okul öncesi eğitim almamış olanlara göre daha yüksek olduğu anlaşılmaktadır. SKEB, GTB, KKEB alt boyutlarında ise gelişimi risk altında olan okul öncesi çocuklarının daha önce okul öncesi eğitim alıp almama durumuna göre sosyal beceri düzeyleri arasında anlamlı bir farkın olmadığ 1 belirlenmiştir.

Tablo 8. Gelişimi Risk Altında Olan Okul Öncesi Çocuklarının Annelerinin Çalışma Durumuna Göre Sosyal Beceri Düzeylerinin Aritmetik Ortalama ve Standart Sapmaları ve t Testi Sonuçları

\begin{tabular}{|c|c|c|c|c|c|c|c|}
\hline Alt Boyutlar & $\begin{array}{c}\text { Annenin Çalışma } \\
\text { Durumu }\end{array}$ & $\mathbf{n}$ & Ortalama & $\begin{array}{l}\text { Standart } \\
\text { Sapma }\end{array}$ & sd & $\mathbf{t}$ & $\mathbf{p}$ \\
\hline \multirow{2}{*}{$\begin{array}{l}\text { SKEB (Sonuçları Kabul Etme } \\
\text { Becerileri) }\end{array}$} & Çalışmıyor & 104 & 2,83 &, 06 & \multirow{2}{*}{133} & \multirow{2}{*}{,826 } & \multirow{2}{*}{, 410} \\
\hline & Çalışıyor & 31 & 2,95 & 17 & & & \\
\hline \multirow{2}{*}{$\begin{array}{l}\text { GTB (Görevleri Tamamlama } \\
\text { Becerileri) }\end{array}$} & Çalışmıyor & 104 & 3,25 &, 08 & \multirow{2}{*}{133} & \multirow{2}{*}{$, 2,45$} & \multirow{2}{*}{, 015} \\
\hline & Çalışıyor & 31 & 2,75 & 23 & & & \\
\hline \multirow{2}{*}{ DB (Dinleme Becerileri) } & Çalışmiyor & 104 & 3,10 & ,06 & \multirow{2}{*}{133} & \multirow{2}{*}{,937 } & \multirow{2}{*}{, 350} \\
\hline & Çalışıyor & 31 & 3,25 &, 17 & & & \\
\hline \multirow{2}{*}{ AOB (Amaç Oluşturma Becerileri) } & Çalışmiyor & 104 & 3,04 & ,09 & \multirow{2}{*}{133} & \multirow{2}{*}{, 277} & \multirow{2}{*}{, 782} \\
\hline & Çalışıyor & 31 & 3,10 & ,22 & & & \\
\hline \multirow{2}{*}{$\begin{array}{l}\text { KKEB (Kendini Kontrol Etme } \\
\text { Becerileri) }\end{array}$} & Çalışmiyor & 104 & 2,98 & ,07 & \multirow{2}{*}{133} & \multirow{2}{*}{,204 } & \multirow{2}{*}{, 839} \\
\hline & Çalışıyor & 31 & 2,94 & 20 & & & \\
\hline \multirow{2}{*}{ SAB (Sözel Açıklama Becerileri) } & Çalışmıyor & 104 & 2,80 & ,09 & \multirow{2}{*}{133} & \multirow{2}{*}{,945 } & \multirow{2}{*}{,346 } \\
\hline & Çalışıyor & 31 & 2,99 &, 20 & & & \\
\hline \multirow{2}{*}{$\begin{array}{l}\text { ABBÇB (Akran Baskısı İle Başa } \\
\text { Çıkma Becerileri) }\end{array}$} & Çalışmıyor & 104 & 2,66 &, 05 & \multirow{2}{*}{133} & \multirow{2}{*}{1,770} & \multirow{2}{*}{,079 } \\
\hline & Çalışıyor & 31 & 2,90 &, 17 & & & \\
\hline \multirow{2}{*}{$\begin{array}{l}\text { KDKEDYSB (Kızgınlık Davranış- } \\
\text { larını Kontrol Etme ve Değişiklik- } \\
\text { lere Uyum Sağlama Becerileri) }\end{array}$} & Çalışmıyor & 104 & 2,90 & ,06 & \multirow{2}{*}{133} & \multirow{2}{*}{,796 } & \multirow{2}{*}{,427 } \\
\hline & Çalışıyor & 31 & 3,02 &, 13 & & & \\
\hline \multirow{2}{*}{ KB (Kişiler Arası Beceriler) } & Çalışmıyor & 104 & 2,94 &, 06 & \multirow{2}{*}{133} & \multirow{2}{*}{,390 } & \\
\hline & Çalışıyor & 31 & 3,00 &, 17 & & & ,09 \\
\hline & Çalışmıyor & 104 & 3,00 & 05 & 33 & $6 / 6$ & 70 \\
\hline GEIVEL & Çalışıyor & 31 & 3,00 & 15 & 153 & , 010 & , 50 \\
\hline
\end{tabular}

Tablo 8'de yer alan bulgular incelendiğinde gelişimi risk altında olan çocukların GTB alt boyutunda annesi çalışmıyor olanların sosyal beceri aritmetik ortalamalarının $(\mathrm{O}=3,25)$ annesi çalışıyor olanların aritmetik ortalamalarına $(\mathrm{O}=2,75)$ göre daha yüksek olduğu görülmektedir. AOB alt boyutunda annesi çalışıyor çocukların aritmetik ortalamalarının $(O=3,10)$ annesi çalışmıyor çocukların aritmetik ortalamalarının $(O=3,04)$ birbirine yakın olduğu görülmektedir. $S A B$ alt boyutunda annesi çalışıyor çocukların sosyal beceri aritmetik ortalamalarının $(O=2,99)$ annesi çalışmıyor çocukların aritmetik ortalamalarının $(\mathrm{O}=2,80)$ birbirine yakın olduğu görülmektedir. ABBÇB alt boyutunda annesi çalışıyor çocukların aritmetik ortalamalarının $(O=2,66)$ annesi çalışmıyor çocukların aritmetik ortalamalarının $(\mathrm{O}=2,90)$ birbirine yakın olduğu görülmektedir. KB alt boyutunda annesi çalışıyor çocukların sosyal beceri aritmetik ortalamalarının $(\mathrm{O}=3,00)$ annesi çalışmıyor çocukların aritmetik ortalamalarının $(\mathrm{O}=2,94)$ birbirine yakın ol- 
duğu görülmektedir. SKEB alt boyutunda gelişimi risk altında olan çocukların annesi çalışmıyor olanların aritmetik ortalamalarının $(\mathrm{O}=2,83)$ annesi çalışıyor olanların aritmetik ortalamalarının $(\mathrm{O}=2,95)$ birbirine yakın olduğu görülmektedir. DB alt boyutunda annesi çalışmıyor olanların aritmetik ortalamalarının $(\mathrm{O}=3,10)$ annesi çalışıyor olanların sosyal beceri aritmetik ortalamalarının $(\mathrm{O}=3,25)$ birbirine yakın olduğu görülmektedir. KKEB alt boyutunda annesi çalışmıyor olanların aritmetik ortalamalarının $(\mathrm{O}=2,98)$ annesi çalışıyor olanların aritmetik ortalamalarının $(\mathrm{O}=2,94)$ birbirine yakın olduğu görülmektedir. KDKEDYSB alt boyutunda annesi çalışmıyor olanların aritmetik ortalamalarının $(\mathrm{O}=2,90)$ annesi çalışıyor olanların aritmetik ortalamalarının $(\mathrm{O}=3,02)$ birbirine yakın olduğu görülmektedir.

Gelişimi risk altında olan annesi çalışan ve çalışmayan okul öncesi çocuklarının sosyal beceri düzeylerinin aritmetik ortalamaları arasındaki farkın anlamlı olup olmadığını ortaya koymak amacıyla yapılan $\mathrm{t}$ testi sonuçlarına göre GTB alt boyutunda iki grup arasındaki fark önemli çıkmıştır, $\mathrm{t}(133)=2,45 ; \mathrm{p}=0,01$. Gelişimi risk altında olan annesi çalışmayan çocukların sosyal beceri düzeylerinin GTB alt boyutunda annesi çalışanlara göre daha yüksek olduğu belirlenmiştir. SKEB, DB, AOB, KKEB, SAB, ABBÇB, KDKEDYSB, KB alt boyutlarında ve genelde iki grup arasındaki farkın önemsiz olduğu saptanmıştır.

Tablo 9. Gelişimi Risk Altında Olan Okul Öncesi Çocuklarının Sağlıksız Kalabalık Konutta Yaşama Durumuna Göre Sosyal Beceri Düzeylerinin Aritmetik Ortalama ve Standart Sapmaları

\begin{tabular}{|c|c|c|c|c|}
\hline Alt Boyutlar & $\begin{array}{c}\text { Sağlıksız Kalabalık } \\
\text { Konutta Yaşama }\end{array}$ & $\mathbf{n}$ & Ortalama & $\begin{array}{l}\text { Standart } \\
\text { Sapma }\end{array}$ \\
\hline \multirow{2}{*}{ SKEB (Sonuçları Kabul Etme Becerileri) } & Evet & 28 & 2,66 &, 08 \\
\hline & Hayır & 107 & 2,92 &, 06 \\
\hline \multirow{2}{*}{ GTB (Görevleri Tamamlama Becerileri) } & Evet & 28 & 2,84 &, 11 \\
\hline & Hayır & 107 & 3,21 & 07 \\
\hline \multirow{2}{*}{ DB (Dinleme Becerileri) } & Evet & 28 & 2,98 &, 16 \\
\hline & Hayır & 107 & 3,17 &, 10 \\
\hline \multirow{2}{*}{ AOB (Amaç Oluşturma Becerileri) } & Evet & 28 & 2,53 &, 12 \\
\hline & Hayır & 107 & 3,19 & 07 \\
\hline \multirow{2}{*}{ KKEB (Kendini Kontrol Etme Becerileri) } & Evet & 28 & 2,70 &, 15 \\
\hline & Hayır & 107 & 3,04 &, 10 \\
\hline \multirow{2}{*}{ SAB (Sözel Açıklama Becerileri) } & Evet & 28 & 2,63 & ,16 \\
\hline & Hayır & 107 & 2,89 &, 08 \\
\hline \multirow{2}{*}{ ABBÇB (Akran Baskısı İle Başa Çıkma Becerileri) } & Evet & 28 & 2,53 & ,16 \\
\hline & Hayır & 107 & 2,76 & ,09 \\
\hline \multirow{2}{*}{$\begin{array}{l}\text { KDKEDYSB (Kızgınlık Davranışlarını Kontrol Etme } \\
\text { ve Değişikliklere Uyum Sağlama Becerileri) }\end{array}$} & Evet & 28 & 2,68 &, 09 \\
\hline & Hayır & 107 & 3,00 & ,06 \\
\hline \multirow{2}{*}{ KB (Kişiler Arası Beceriler) } & Evet & 28 & 2,63 &, 08 \\
\hline & Hayır & 107 & 3,04 & 07 \\
\hline \multirow{2}{*}{ GENEL } & Evet & 28 & 2,66 &, 08 \\
\hline & Hayır & 107 & 2,99 &, 06 \\
\hline
\end{tabular}

Tablo 9'da yer alan bulgular incelendiğinde AOB alt boyutunda gelişimi risk altında olan sağlıksız kalabalık konutta yaşamayan çocukların aritmetik ortalamalarının $(O=3,19)$ sağlıksız kalabalık konutta yaşayan çocukların aritmetik ortalamalarına $(\mathrm{O}=2,53)$ göre daha yüksek olduğu ve KDKEDYSB alt boyutunda sağlıksız kalabalık konutta yaşamayanların aritmetik ortalamalarının $(\mathrm{O}=3,00)$ sağlıksız kalabalık konutta yaşayan çocukların aritmetik ortalamala- 
rına $(\mathrm{O}=2,68)$ göre daha yüksek olduğu görülmektedir. $\mathrm{KB}$ alt boyutunda sağlıksız kalabalık konutta yaşamayanların aritmetik ortalamalarının $(\mathrm{O}=3,04)$ sağlıksız kalabalık konutta yaşayan çocukların aritmetik ortalamalarına $(\mathrm{O}=2,63)$ göre daha yüksek olduğu ve genel otalamada da gelişimi risk altında olan sağlıksız kalabalık konutta yaşamayan çocukların aritmetik ortalamalarının $(\mathrm{O}=2,99)$ sağlıksız kalabalık konutta yaşayan çocukların aritmetik ortalamalarına $(\mathrm{O}=2,66)$ göre daha yüksek olduğu görülmektedir.

SKEB alt boyutunda gelişimi risk altında olan sağlıksız kalabalık konutta yaşamayan çocukların sosyal beceri aritmetik ortalamalarıyla $(O=2,92)$ sağlıksız kalabalık konutta yaşayanların aritmetik ortalamalarının $(\mathrm{O}=2,66)$ birbirine yakın olduğu görülmektedir. GTB alt boyutunda sağlıksız kalabalık konutta yaşamayan çocukların sosyal beceri aritmetik ortalamalarıyla $(O=3,21)$ sağlıksız kalabalık konutta yaşayan çocukların aritmetik ortalamalarının $(O=2,84)$ birbirine yakın olduğu görülmektedir. DB alt boyutunda sağliksız kalabalık konutta yaşamayan çocukların sosyal beceri aritmetik ortalamalarıyla $(O=3,17)$ sağlıksız kalabalık konutta yaşayan çocukların aritmetik ortalamalarının $(\mathrm{O}=2,98)$ birbirine yakın olduğu görülmektedir. KKEB alt boyutunda alt boyutunda sağlıksız kalabalık konutta yaşamayan çocukların sosyal beceri sosyal beceri aritmetik ortalamalarıyla $(\mathrm{O}=3,04)$ sağlıksız kalabalık konutta yaşayan çocukların aritmetik ortalamalarının $(\mathrm{O}=2,70)$ birbirine yakın olduğu görülmektedir. SAB alt boyutunda sağlıksız kalabalık konutta yaşamayan çocukların aritmetik ortalamalarıyla $(O=2,89)$ sağlıksız kalabalık konutta yaşayan çocukların sosyal beceri aritmetik ortalamalarının $(\mathrm{O}=2,63)$ birbirine yakın olduğu görülmektedir. ABBÇB alt boyutunda sağlıksız kalabalık konutta yaşamayan çocukların aritmetik ortalamalarıyla $(\mathrm{O}=2,76)$ sağlıksız kalabalık konutta yaşayan çocukların aritmetik ortalamalarının $(\mathrm{O}=2,53)$ birbirine yakın olduğu görülmektedir.

Gelişimi risk altında olan sağlıksız kalabalık konutta yaşayan ve yaşamayan okul öncesi çocuklarının sosyal beceri düzeylerinin aritmetik ortalamaları arasındaki farkın anlamlı olup olmadığını ortaya koymak amacıyla yapılan Mann Whitney U Testi sonuçları Tablo 10'da yer almaktadir.

Tablo 10. Gelişimi Risk Altında Olan Okul Öncesi Çocuklarının Sağlıksız Kalabalık Konutta Yaşama Durumuna Göre Sosyal Beceri Düzeylerinin Mann Whitney U Testi Sonuçları

\begin{tabular}{|c|c|c|c|c|c|c|c|}
\hline Alt Boyutlar & $\begin{array}{c}\text { Sağlıksız Kalabalık } \\
\text { Konutta Yaşama }\end{array}$ & $\mathbf{n}$ & $\begin{array}{c}\text { Sira } \\
\text { Ortalaması }\end{array}$ & $\begin{array}{c}\text { Sira } \\
\text { Toplamı }\end{array}$ & $\mathbf{U}$ & $\mathbf{p}$ & $\begin{array}{c}\text { Önem } \\
\text { Denetimi }\end{array}$ \\
\hline \multirow{2}{*}{$\begin{array}{l}\text { SKEB (Sonuçları } \\
\text { Kabul Etme } \\
\text { Becerileri) }\end{array}$} & Evet & 28 & 56,98 & 1595,50 & \multirow{2}{*}{1189,50} & \multirow{2}{*}{087} & \multirow{2}{*}{$\begin{array}{c}\text { Fark } \\
\text { Önemsiz }\end{array}$} \\
\hline & Hayır & 107 & 70,88 & 7584,50 & & & \\
\hline \multirow{2}{*}{$\begin{array}{l}\text { GTB (Görevleri } \\
\text { Tamamlama } \\
\text { Becerileri) }\end{array}$} & Evet & 28 & 57,68 & 1615,00 & \multirow{2}{*}{1209,00} & \multirow{2}{*}{,109 } & \multirow{2}{*}{$\begin{array}{c}\text { Fark } \\
\text { Önemsiz }\end{array}$} \\
\hline & Hayır & 107 & 70,70 & 7565,00 & & & \\
\hline \multirow{2}{*}{$\begin{array}{l}\text { DB (Dinleme } \\
\text { Becerileri) }\end{array}$} & Evet & 28 & 60,46 & 1693,00 & \multirow{2}{*}{1287,00} & \multirow{2}{*}{,248 } & \multirow{2}{*}{$\begin{array}{c}\text { Fark } \\
\text { Önemsiz }\end{array}$} \\
\hline & Hayır & 107 & 69,97 & 7487,00 & & & \\
\hline \multirow{2}{*}{$\begin{array}{l}\text { AOB (Amaç } \\
\text { Oluşturma } \\
\text { Becerileri) }\end{array}$} & Evet & 28 & 49,46 & 1385,00 & \multirow{2}{*}{979,00} & \multirow{2}{*}{,004 } & \multirow{2}{*}{$\begin{array}{c}\text { Fark } \\
\text { Önemli }\end{array}$} \\
\hline & Hayır & 107 & 72,85 & 7795,00 & & & \\
\hline \multirow{2}{*}{$\begin{array}{l}\text { KKEB (Kendini } \\
\text { Kontrol Etme } \\
\text { Becerileri) }\end{array}$} & Evet & 28 & 56,63 & 1585,00 & \multirow[t]{2}{*}{1179,50} & \multirow{2}{*}{,082 } & \multirow{2}{*}{$\begin{array}{c}\text { Fark } \\
\text { Önemsiz }\end{array}$} \\
\hline & Hayır & 107 & 70,98 & 7594,00 & & & \\
\hline SAB (Sözel Açık- & Evet & 28 & 58,61 & 1641,00 & 1235,00 &, 152 & Fark \\
\hline
\end{tabular}




\begin{tabular}{|c|c|c|c|c|c|c|c|}
\hline lama Becerileri) & Hayır & 107 & 70,46 & 7539,00 & & & Önemsiz \\
\hline \multirow{2}{*}{$\begin{array}{l}\text { ABBÇB (Akran } \\
\text { Baskısı İle Başa } \\
\text { Çıkma Becerileri) }\end{array}$} & Evet & 28 & 55,27 & 1547,50 & \multirow{2}{*}{1141,50} & \multirow[b]{2}{*}{,052 } & \multirow{2}{*}{$\begin{array}{c}\text { Fark } \\
\text { Önemsiz }\end{array}$} \\
\hline & Hayır & 107 & 71,33 & 7632,50 & & & \\
\hline \multirow{2}{*}{$\begin{array}{l}\text { KDKEDYSB } \\
\text { (Kızgınlık Davra- } \\
\text { nışlarını Kontrol } \\
\text { Etme ve Değişiklik- } \\
\text { lere Uyum Sağlama } \\
\text { Becerileri) }\end{array}$} & Evet & 28 & 53,05 & 1485,50 & \multirow{2}{*}{1079,50} & \multirow{2}{*}{, 023} & \multirow{2}{*}{$\begin{array}{l}\text { Fark } \\
\text { Önemli }\end{array}$} \\
\hline & Hayır & 107 & 71,91 & 7694,50 & & & \\
\hline \multirow{2}{*}{$\begin{array}{l}\text { KB (Kişiler Arası } \\
\text { Beceriler) }\end{array}$} & Evet & 28 & 50,34 & 1409,50 & \multirow{2}{*}{1003,50} & \multirow{2}{*}{,007 } & \multirow{2}{*}{$\begin{array}{c}\text { Fark } \\
\text { Önemli }\end{array}$} \\
\hline & Hayır & 107 & 72,62 & 7770,50 & & & \\
\hline \multirow{2}{*}{ GENEL } & Evet & 28 & 52,14 & 1460,00 & \multirow{2}{*}{1054,00} & \multirow{2}{*}{,016 } & \multirow{2}{*}{$\begin{array}{l}\text { Fark } \\
\text { Önemli }\end{array}$} \\
\hline & Hayır & 107 & 72,15 & 7720,00 & & & \\
\hline
\end{tabular}

Tablo 10'da yer alan bulgular incelendiğinde gelişimi risk altında olan okul öncesi çocuklarının sağlıksız kalabalık konutta yaşayıp yaşama durumuna göre sosyal beceri düzeylerinin Mann Whitney U Testi sonuçlarında AOB alt boyutunda $(\mathrm{U}=979,000, \mathrm{p}<0.05), \mathrm{KB}$ alt boyutunda $(\mathrm{U}=1003,50, \mathrm{p}<0.05)$, KDKEDYSB alt boyutunda $(\mathrm{U}=1079,50, \mathrm{p}<0.05)$ ve genelde $(\mathrm{U}=885,50, \mathrm{p}<0.05)$ gelişimi risk altında olan okul öncesi çocuklarının göre anlamlı bir fark olduğu görülmektedir. Bu alt boyutlarda ve genelde sağlıksız kalabalık konutta yaşayıp yaşama durumuna göre sıra ortalamaları dikkate alındığında sağlıksız kalabalık konutta yaşamayan gelişimi risk altında olan çocukların sosyal becerilerinin sağlıksız kalabalık konutta yaşayanlara göre daha yüksek olduğu anlaşılmaktadır. SKEB, GTB, DB, KKEB, SAB, ABBÇB alt boyutlarında ise gelişimi risk altında olan okul öncesi çocuklarının sağlıksız kalabalık konutta yaşayıp yaşama durumuna göre sosyal beceri düzeyleri arasında anlamlı bir farkın olmadığı belirlenmiştir.

Tablo 11. Gelişimi Risk Altında Olan Okul Öncesi Çocuklarının Ev Ortamındaki Fiziksel Çevrenin Durumuna Göre Sosyal Beceri Düzeylerinin Aritmetik Ortalama ve Standart Sapmaları ve t Testi Sonuçları

\begin{tabular}{|c|c|c|c|c|c|c|c|}
\hline Alt Boyutlar & $\begin{array}{c}\text { Ev Ortamındaki } \\
\text { Fiziksel Çevrenin } \\
\text { Durumu }\end{array}$ & $\mathbf{n}$ & Ortalama & $\begin{array}{l}\text { Standart } \\
\text { Sapma }\end{array}$ & sd & $\mathbf{t}$ & $\mathbf{p}$ \\
\hline \multirow{2}{*}{$\begin{array}{l}\text { SKEB (Sonuçları Kabul Etme } \\
\text { Becerileri) }\end{array}$} & Uygun Değil & 100 & 2,75 &, 51 & \multirow{2}{*}{133} & \multirow{2}{*}{3,33} & \multirow{2}{*}{,001 } \\
\hline & Uygun & 35 & 3,20 & 1.04 & & & \\
\hline \multirow{2}{*}{$\begin{array}{l}\text { GTB (Görevleri Tamamlama } \\
\text { Becerileri) }\end{array}$} & Uygun Değil & 100 & 3,07 &, 81 & \multirow{2}{*}{133} & \multirow{2}{*}{1,32} & \multirow{2}{*}{, 187 } \\
\hline & Uygun & 35 & 3,33 & 1,43 & & & \\
\hline \multirow{2}{*}{ DB (Dinleme Becerileri) } & Uygun Değil & 100 & 3,00 &, 54 & \multirow{2}{*}{133} & \multirow{2}{*}{3,46} & \multirow{2}{*}{,001 } \\
\hline & Uygun & 35 & 3,51 & 1,15 & & & \\
\hline \multirow{2}{*}{$\begin{array}{l}\text { AOB (Amaç Oluşturma } \\
\text { Becerileri) }\end{array}$} & Uygun Değil & 100 & 2,95 &, 82 & \multirow{2}{*}{133} & \multirow{2}{*}{1,99} & \multirow{2}{*}{, 048} \\
\hline & Uygun & 35 & 3,36 & 1,47 & & & \\
\hline \multirow{2}{*}{$\begin{array}{l}\text { KKEB (Kendini Kontrol Etme } \\
\text { Becerileri) }\end{array}$} & Uygun Değil & 100 & 2,87 &, 72 & \multirow{2}{*}{133} & \multirow{2}{*}{2,23} & \multirow{2}{*}{, 027} \\
\hline & Uygun & 35 & 3,25 & 1,20 & & & \\
\hline \multirow{2}{*}{$\begin{array}{l}\text { SAB (Sözel Açılama } \\
\text { Becerileri) }\end{array}$} & Uygun Değil & 100 & 2,65 &, 78 & \multirow{2}{*}{133} & \multirow{2}{*}{3,96} & \multirow{2}{*}{, 000} \\
\hline & Uygun & 35 & 3,37 & 1,23 & & & \\
\hline \multirow{2}{*}{$\begin{array}{l}\text { ABBÇB (Akran Baskısı İle } \\
\text { Başa Çıkma Becerileri) }\end{array}$} & Uygun Değil & 100 & 2,63 &, 46 & \multirow{2}{*}{133} & \multirow{2}{*}{2,50} & \multirow{2}{*}{,013 } \\
\hline & Uygun & 35 & 2,95 & 1,01 & & & \\
\hline
\end{tabular}




\begin{tabular}{|c|c|c|c|c|c|c|c|}
\hline \multirow{2}{*}{$\begin{array}{l}\text { KDKEDYSB (Kızgınlık } \\
\text { Davranışlarını Kontrol Etme ve } \\
\text { Değişikliklere Uyum Sağlama } \\
\text { Becerileri) }\end{array}$} & Uygun Değil & 100 & 2,81 &, 50 & \multirow{2}{*}{133} & \multirow{2}{*}{3,58} & \multirow{2}{*}{,000 } \\
\hline & Uygun & 35 & 3,28 & ,99 & & & \\
\hline \multirow{2}{*}{ KB (Kişiler Arası Beceriler) } & Uygun Değil & 100 & 2,80 &, 52 & \multirow{2}{*}{133} & \multirow{2}{*}{4,43} & \multirow{2}{*}{, 000} \\
\hline & Uygun & 35 & 3,42 & 1,08 & & & \\
\hline \multirow{2}{*}{ GENEL } & Uygun Değil & 100 & 2,79 & ,40 & \multirow{2}{*}{133} & \multirow{2}{*}{4,05} & \multirow{2}{*}{000} \\
\hline & Uygun & 35 & 3,29 & 1,01 & & & \\
\hline
\end{tabular}

Tablo 11'de yer alan bulgular incelendiğinde gelişimi risk altında olan çocukların SKEB alt boyutunda ev ortamı fiziksel olarak uygun olanların sosyal beceri aritmetik ortalamalarının $(\mathrm{O}=3,20)$ uygun olmayanların ortalamalarına $(\mathrm{O}=2,75)$ göre daha yüksek olduğu görülmektedir. GTB alt boyutunda ev ortamı fiziksel olarak uygun olanların sosyal beceri aritmetik ortalamalarının $(\mathrm{O}=3,33)$, uygun olmayanların aritmetik ortalamalarının $(\mathrm{O}=3,07)$ birbirine yakın olduğu görülmektedir. DB alt boyutunda ev ortamı fiziksel olarak uygun olanların aritmetik ortalamalarının $(\mathrm{O}=3,51)$ uygun olmayanların sosyal beceri aritmetik ortalamalarına $(\mathrm{O}=3,00)$ göre daha yüksek olduğu görülmektedir. $\mathrm{AOB}$ alt boyutunda ev ortamı fiziksel olarak uygun olanların sosyal beceri aritmetik ortalamalarının $(\mathrm{O}=3,36)$ uygun olmayanların aritmetik ortalamalarına $(\mathrm{O}=2,95)$ göre daha yüksek olduğu görülmektedir. KKEB alt boyutunda ev ortamı fiziksel olarak uygun olanların sosyal beceri aritmetik ortalamalarının $(\mathrm{O}=3,25)$ uygun olmayanların aritmetik ortalamalarına $(\mathrm{O}=2,87)$ göre daha yüksek olduğu görülmektedir. $\mathrm{SAB}$ alt boyutunda ev ortamı fiziksel olarak uygun olanların sosyal beceri aritmetik ortalamalarının $(\mathrm{O}=3,37)$ uygun olmayanların aritmetik ortalamalarına $(\mathrm{O}=2,65)$ göre daha yüksek olduğu görülmektedir. $\mathrm{ABBÇB}$ alt boyutunda ev ortamı fiziksel olarak uygun olanların sosyal beceri aritmetik ortalamalarının $(\mathrm{O}=2,95)$ uygun olmayanların aritmetik ortalamalarına $(\mathrm{O}=2,63)$ göre daha yüksek olduğu görülmektedir. KDKEDYSB alt boyutunda ev ortamı fiziksel olarak uygun olanların sosyal beceri aritmetik ortalamalarının $(\mathrm{O}=3,28)$ uygun olmayanların aritmetik ortalamalarına $(\mathrm{O}=2,81)$ göre daha yüksek olduğu görülmektedir. $\mathrm{KB}$ alt boyutunda ev ortamı fiziksel olarak uygun olanların sosyal beceri aritmetik ortalamalarının $(\mathrm{O}=3,43)$ uygun olmayanların aritmetik ortalamalarına $(\mathrm{O}=2,80)$ göre daha yüksek olduğu ve genel ortalamada da ev ortamı fiziksel olarak uygun olanların sosyal beceri aritmetik ortalamalarının $(O=3,29)$ uygun olmayanların aritmetik ortalamalarına $(\mathrm{O}=2,79)$ göre daha yüksek olduğu görülmektedir.

Gelişimi risk altında olan ev ortamındaki fiziksel çevre uygun olan ve uygun olmayan okul öncesi çocuklarının sosyal beceri düzeylerinin aritmetik ortalamaları arasındaki farkın anlamlı olup olmadığını ortaya koymak amacıyla yapılan t testi sonuçlarına göre SKEB alt boyutunda, $\mathrm{t}(133)=3,33 ; \mathrm{p}<0.05$, DB alt boyutunda, $\mathrm{t}(133)=3,46 ; \mathrm{p}=0.01$, AOB alt boyutunda $\mathrm{t}(133)=1,99$; $\mathrm{p}=0.04$, KKEB alt boyutunda $\mathrm{t}(133)=2,23 ; \mathrm{p}=0.02$, SAB alt boyutunda $\mathrm{t}(133)=3,96 ; \mathrm{p}<0.05$, $A B B C ̧ B$ alt boyutunda $t(133)=2,50 ; p=0.01$, KDKEDYSB alt boyutunda $t(133)=3,58 ; p<0.05$, $\mathrm{KB}$ alt boyutunda $\mathrm{t}(133)=4,43 ; \mathrm{p}<0.05$ iki grup arasındaki fark önemli çıkmıştır. GTB alt boyutunda ise iki grup arasındaki farkın önemsiz olduğu saptanmıştır.

Gelişimi risk altında olan ev ortamındaki fiziksel çevre uygun olan çocukların sosyal beceri düzeylerinin SKEB, DB, AOB, KKEB, SAB, ABBÇB, KDKEDYSB, KB alt boyutlarında ev ortamındaki fiziksel çevre uygun olmayanlara göre daha yüksek olduğu belirlenmiştir. 
Tablo 12. Gelişimi Risk Altında Olan Okul Öncesi Çocuklarının Evdeki Psiko-sosyal Ortamın Durumuna Göre Sosyal Beceri Düzeylerinin Aritmetik Ortalama ve Standart Sapmaları

\begin{tabular}{|c|c|c|c|c|}
\hline Alt Boyutlar & $\begin{array}{l}\text { Evdeki Psiko-sosyal } \\
\text { Ortamın Durumu }\end{array}$ & $\mathbf{n}$ & Ortalama & $\begin{array}{l}\text { Standart } \\
\text { Sapma }\end{array}$ \\
\hline \multirow{2}{*}{ SKEB (Sonuçları Kabul Etme Becerileri) } & Olumsuz & 107 & 2,72 &, 53 \\
\hline & Olumlu & 28 & 3,44 & 1,0 \\
\hline \multirow{2}{*}{ GTB (Görevleri Tamamlama Becerileri) } & Olumsuz & 107 & 2,98 & 87 \\
\hline & Olumlu & 28 & 3,75 & 1,29 \\
\hline \multirow{2}{*}{ DB (Dinleme Becerileri) } & Olumsuz & 107 & 2,97 &, 57 \\
\hline & Olumlu & 28 & 3,78 & 1,11 \\
\hline \multirow{2}{*}{ AOB (Amaç Oluşturma Becerileri) } & Olumsuz & 107 & 2,87 &, 86 \\
\hline & Olumlu & 28 & 3,79 & ,80 \\
\hline \multirow{2}{*}{ KKEB (Kendini Kontrol Etme Becerileri) } & Olumsuz & 107 & 2,83 & 1,38 \\
\hline & Olumlu & 28 & 3,50 &, 76 \\
\hline \multirow{2}{*}{ SAB (Sözel Açıklama Becerileri) } & Olumsuz & 107 & 2,60 & 1,13 \\
\hline & Olumlu & 28 & 3,78 &, 79 \\
\hline \multirow{2}{*}{$\begin{array}{l}\text { ABBÇB (Akran Baskısı İle Başa Çıkma } \\
\text { Becerileri) }\end{array}$} & Olumsuz & 107 & 2,58 & 1,07 \\
\hline & Olumlu & 28 & 3,22 &, 51 \\
\hline \multirow{2}{*}{$\begin{array}{l}\text { KDKEDYSB (Kızgınlık Davranışlarını Kontrol } \\
\text { Etme ve Değişikliklere Uyum Sağlama Becerileri) }\end{array}$} & Olumsuz & 107 & 2,78 & ,93 \\
\hline & Olumlu & 28 & 3,53 &, 53 \\
\hline \multirow{2}{*}{ KB (Kişiler Arası Beceriler) } & Olumsuz & 107 & 2,76 &, 55 \\
\hline & Olumlu & 28 & 3,75 & ,96 \\
\hline \multirow{2}{*}{ GENEL } & Olumsuz & 107 & 2,75 & 44 \\
\hline & Olumlu & 28 & 3,60 & ,90 \\
\hline
\end{tabular}

Tablo 12'de yer alan bulgular incelendiğinde gelişimi risk altında olan çocukların SKEB alt boyutunda ev ortamı psiko-sosyal açıdan olumlu olanların sosyal beceri aritmetik ortalamalarının $(\mathrm{O}=3,44)$ olumsuz olanların aritmetik ortalamalarına $(\mathrm{O}=2,72)$ göre daha yüksek olduğu görülmektedir. GTB alt boyutunda ev ortamı psiko-sosyal açıdan olumlu olanların sosyal beceri aritmetik ortalamalarının $(\mathrm{O}=3,75)$, olumsuz olanların aritmetik ortalamalarına $(\mathrm{O}=2,98)$ göre daha yüksek olduğu görülmektedir. DB alt boyutunda ev ortamı psiko-sosyal açıdan olumlu olanların sosyal beceri aritmetik ortalamalarının $(\mathrm{O}=3,78)$ olumsuz olanların aritmetik ortalamalarına $(\mathrm{O}=2,97)$ göre daha yüksek olduğu görülmektedir. AOB alt boyutunda ev ortamı psiko-sosyal açıdan olumlu olanların sosyal beceri aritmetik ortalamalarının $(\mathrm{O}=3,79)$, olumsuz olanların aritmetik ortalamalarına $(\mathrm{O}=2,87)$ göre daha yüksek olduğu görülmektedir. KKEB alt boyutunda ev ortamı psiko-sosyal açıdan olumlu olanların sosyal beceri aritmetik ortalamalarının $(\mathrm{O}=3,50)$ olumsuz olanların aritmetik ortalamalarına $(\mathrm{O}=2,83)$ göre daha yüksek olduğu görülmektedir. SAB alt boyutunda ev ortamı psiko-sosyal açıdan olumlu olanların sosyal beceri aritmetik ortalamalarının $(O=3,78)$ olumsuz olanların aritmetik ortalamalarına $(O=2,60)$ göre daha yüksek olduğu görülmektedir. $\mathrm{ABBÇB}$ alt boyutunda ev ortamı psiko-sosyal açıdan olumlu olanların sosyal beceri aritmetik ortalamalarının $(\mathrm{O}=3,22)$ olumsuz olanların aritmetik ortalamalarına $(\mathrm{O}=2,58)$ göre daha yüksek olduğu görülmektedir. KDKEDYSB alt boyutunda ev ortamı psiko-sosyal açıdan olumlu olanların sosyal beceri aritmetik ortalamalarının $(\mathrm{O}=3,53)$ olumsuz olanların aritmetik ortalamalarına $(\mathrm{O}=2,76)$ göre daha yüksek olduğu görülmektedir. $\mathrm{KB}$ alt boyutunda ev ortamı psiko-sosyal açıdan olumlu olanların sosyal beceri aritmetik ortalamalarının $(\mathrm{O}=3,75)$ olumsuz olanların aritmetik ortalamalarına $(\mathrm{O}=2,76)$ göre daha yüksek olduğu ve genel ortalamada da ev ortamı psiko-sosyal açıdan olumlu olanların sosyal beceri 
aritmetik ortalamalarının $(\mathrm{O}=3,60)$ olumsuz olanların aritmetik ortalamalarına $(\mathrm{O}=2,75)$ göre daha yüksek olduğu görülmektedir.

Gelişimi risk altında olan evdeki psiko-sosyal ortamı olumlu ve olumsuz okul öncesi çocuklarının sosyal beceri düzeylerinin aritmetik ortalamaları arasındaki farkın anlamlı olup olmadığını ortaya koymak amacıyla yapılan Mann Whitney U Testi sonuçlanı Tablo 13'te yer almaktadır.

Tablo 13. Gelişimi Risk Altında Olan Okul Öncesi Çocuklarının Evdeki Psiko-sosyal Ortamın Durumuna Göre Sosyal Beceri Düzeylerinin Mann Whitney U Testi Sonuçları

\begin{tabular}{|c|c|c|c|c|c|c|c|}
\hline Alt Boyutlar & $\begin{array}{l}\text { Evdeki Psiko-sosyal } \\
\text { Ortamın Durumu }\end{array}$ & $\mathbf{n}$ & $\begin{array}{c}\text { Sira } \\
\text { Ortalaması }\end{array}$ & $\begin{array}{c}\text { Sira } \\
\text { Toplamı }\end{array}$ & $\mathbf{U}$ & $\mathbf{p}$ & $\begin{array}{c}\text { Önem } \\
\text { Denetimi }\end{array}$ \\
\hline \multirow{2}{*}{$\begin{array}{l}\text { SKEB (Sonuçları } \\
\text { Kabul Etme } \\
\text { Becerileri) }\end{array}$} & Olumsuz & 107 & 60,29 & 6451,50 & \multirow{2}{*}{673,500} & \multirow{2}{*}{, 000} & \multirow{2}{*}{$\begin{array}{c}\text { Fark } \\
\text { Önemli }\end{array}$} \\
\hline & Olumlu & 28 & 90,06 & 2593,50 & & & \\
\hline \multirow{2}{*}{$\begin{array}{l}\text { GTB (Görevleri } \\
\text { Tamamlama } \\
\text { Becerileri) }\end{array}$} & Olumsuz & 107 & 62,12 & 6647,00 & \multirow{2}{*}{869,000} & \multirow{2}{*}{, 001} & \multirow{2}{*}{$\begin{array}{c}\text { Fark } \\
\text { Önemli }\end{array}$} \\
\hline & Olumlu & 28 & 88,81 & 2398,00 & & & \\
\hline \multirow{2}{*}{$\begin{array}{l}\text { DB (Dinleme } \\
\text { Becerileri) }\end{array}$} & Olumsuz & 107 & 60,71 & 6495,50 & \multirow{2}{*}{717,500} & \multirow{2}{*}{, 000} & \multirow{2}{*}{$\begin{array}{c}\text { Fark } \\
\text { Önemli }\end{array}$} \\
\hline & Olumlu & 28 & 94,43 & 2549,50 & & & \\
\hline \multirow{2}{*}{$\begin{array}{l}\text { AOB (Amaç } \\
\text { Oluşturma Becerileri) }\end{array}$} & Olumsuz & 107 & 61,57 & 6587,50 & \multirow{2}{*}{809,500} & \multirow{2}{*}{, 000} & \multirow{2}{*}{$\begin{array}{c}\text { Fark } \\
\text { Önemli }\end{array}$} \\
\hline & Olumlu & 28 & 91,02 & 2457,50 & & & \\
\hline \multirow{2}{*}{\begin{tabular}{|l|} 
KKEB (Kendini \\
Kontrol Etme \\
Becerileri) \\
\end{tabular}} & Olumsuz & 107 & 61,53 & 6583,50 & \multirow{2}{*}{805,500} & \multirow{2}{*}{, 000} & \multirow{2}{*}{$\begin{array}{c}\text { Fark } \\
\text { Önemli }\end{array}$} \\
\hline & Olumlu & 28 & 91,17 & 2461,50 & & & \\
\hline \multirow{2}{*}{$\begin{array}{l}\text { SAB (Sözel } \\
\text { Açıklama Becerileri) }\end{array}$} & Olumsuz & 107 & 58,31 & 6239,50 & \multirow{2}{*}{461,500} & \multirow{2}{*}{, 000} & \multirow{2}{*}{$\begin{array}{c}\text { Fark } \\
\text { Önemli }\end{array}$} \\
\hline & Olumlu & 28 & 103,91 & 2805,50 & & & \\
\hline \multirow{2}{*}{$\begin{array}{l}\text { ABBÇB (Akran } \\
\text { Baskısı İle Başa } \\
\text { Çıkma Becerileri) } \\
\end{array}$} & Olumsuz & 107 & 59,94 & 6413,50 & \multirow[t]{2}{*}{635,500} & \multirow[t]{2}{*}{, 000} & \multirow{2}{*}{$\begin{array}{l}\text { Fark } \\
\text { Önemli }\end{array}$} \\
\hline & Olumlu & 28 & 97,46 & 2631,50 & & & \\
\hline \multirow{2}{*}{\begin{tabular}{|l|} 
KDKEDYSB \\
(Kızgınlık Davranışla- \\
rını Kontrol Etme ve \\
Değişikliklere Uyum \\
Sağlama Becerileri) \\
\end{tabular}} & Olumsuz & 107 & 59,23 & 6338,00 & \multirow{2}{*}{603,500} & \multirow{2}{*}{, 000} & \multirow{2}{*}{$\begin{array}{c}\text { Fark } \\
\text { Önemli }\end{array}$} \\
\hline & Olumlu & 28 & 100,26 & 2707,00 & & & \\
\hline \multirow{2}{*}{$\begin{array}{l}\text { KB (Kişiler Aras1 } \\
\text { Beceriler) }\end{array}$} & Olumsuz & 107 & 59,64 & 6381,50 & \multirow{2}{*}{560,000} & \multirow{2}{*}{, 000} & Fark \\
\hline & Olumlu & 28 & 98,65 & 2663,50 & & & Önemli \\
\hline & Olumsuz & 107 & 58,86 & 6298,50 & & 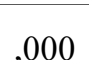 & Fark \\
\hline & Olumlu & 28 & 101,72 & 2746,50 & & , & Önemli \\
\hline
\end{tabular}

Tablo 13'te yer alan bulgular incelendiğinde gelişimi risk altında olan okul öncesi çocuklarının evdeki psiko-sosyal ortamın durumuna göre sosyal beceri düzeylerinin Mann Whitney U Testi sonuçlarında SKEB alt boyutunda $(U=673,500, p<0.05)$, GTB alt boyutunda $(U=869,000, p=$ $0.01)$, DB alt boyutunda $(U=717,500 \mathrm{p}<0.05)$, AOB alt boyutunda $(\mathrm{U}=809,500, \mathrm{p}<0.05)$, KKEB alt boyutunda $(\mathrm{U}=805,500, \mathrm{p}<0.05)$, SAB alt boyutunda $(\mathrm{U}=461,500, \mathrm{p}<0.05)$, ABBÇB alt boyutunda $(U=635,500, p<0.05), K B$ alt boyutunda $(U=560,000, p<0.05)$, KDKEDYSB alt boyutunda $(U=603,500, p<0.05)$ ve genelde $(U=520,500, p<0.05)$ gelişimi risk altında olan okul öncesi çocuklarının göre anlamlı bir fark olduğu görülmektedir. Tüm alt boyutlarda ve genelde, evdeki psiko-sosyal ortamın durumuna göre sıra ortalamaları dikkate alındığında evdeki psiko-sosyal ortamı olumlu olan gelişimi risk altındaki çocukların sosyal be- 
cerilerinin evdeki psiko-sosyal ortamı olumsuz olan çocuklara göre daha yüksek olduğu anlaşılmaktadır.

\section{Sonuç, Tartışma ve Öneriler}

$\mathrm{Bu}$ araştırmanın sonunda gelişimi risk altında olan okul öncesi çocuklarının sosyal beceri düzeylerinin düşük olduğu, gelişimi risk altında olan okul öncesi çocuklarının sosyal beceri düzeylerinin engel durumlarına, ailenin sosyo-kültürel özelliklerine, çocuğun yaşadığı ortama göre farkl11ıklar gösterdiği belirlenmiştir.

Ailesi ile birlikte yaşayan alt sosyo-ekonomik düzeyden gelen çocuklarda yaşıtlarına göre gerilikler olabilmektedir. Ancak nitelikli okul öncesi eğitimden geçen çocuklar diğer çocuklarla aralarındaki farkı kapatabilmektedirler. (Akman 2002). Bu konuyla ilgili yapılan bir araştırmada kaliteli eğitim veren anaokullarına devam eden alt sosyo-ekonomik düzeydeki 3-4 yaş çocuklarını anaokulu deneyimi olmayan çocuklarla karşılaştırma yapılmış ve verilen kaliteli eğitimin çocukların motor, fiziksel ve dil gelişimine olumlu etki yaptığı ancak bu çocukların daha az işbirliğine yatkın olduklarını belirlemişlerdir (Schwartz et al. 1974). Başka bir araştırmada ise sosyo-ekonomik düzeye göre, düşük sosyo-ekonomik düzeyde olan ailelerin çocuklarının üst sosyo-ekonomik düzeydeki ailelerin çocuklarına göre davranış problemlerini daha fazla sergiledikleri görülmüştür (Holland, Holland \& Gimpel 2003). Connor (2002), alt sosyo-ekonomik düzeydeki ailelerde büyüyen çocukların, davranış problemleri olarak, önemli risklere sahip olduklarını belirtmektedir. Seven (2007) de araştırmasında sosyal davranış problemlerinin alt sosyo-ekonomik düzeyden üst sosyo-ekonomik düzeye doğru kademeli olarak azaldığını ortaya çıkarmıştır. Bu araştırmada örnekleme düşük sosyo-ekonomik düzeyde olan ailelerin çocukları seçilmiştir. Düşük sosyo-ekonomik düzey çalışmanın başlıca bir risk faktörü olarak kabul edilmiş ve bu risk faktörüne sahip çocukların sosyal beceri düzeyleri çeşitli değişkenlerle ilişkilendirilerek incelenmiştir. Araştırmada genel olarak düşük sosyo-ekonomik düzeyde gelişimi risk altında olan okul öncesi çocuklarının sosyal beceri düzeylerinin düşük olduğu bulunmuştur. Seven'in araştırmasının sonucu bu araştırma sonuçları ile benzerlik göstermektedir.

Erken çocukluk dönemindeki engelli çocuklarda normal gelişim gösteren akranlarına göre sorun davranışların daha yaygın görüldüğü belirlenmiştir (McIntyre, Blacher \& Baker 2006). Araştırmalar engelli çocukların normal gelişim gösteren çocuklara göre daha az sosyal ilişki kurduklarını göstermektedir (Gülay \& Akman 2009). Bu aynı zamanda sosyal beceriler konusundaki yetersizliklerinin de bir göstergesi olmaktadır. Bu araştırmada da gelişimi risk altında olan engelli çocukların sosyal becerilerinin engelsiz çocuklara göre daha düşük çıkması bu nedene bağlanabilir.

Aral ve arkadaşlarının (2006) yapmış oldukları çalışmada, üniversite mezunu annelerin çocuklarının hem işbirliği hem de sosyal ilişkilerde ortalama puanlarının daha yüksek olduğu sonucuna ulaşılmıştır. Karaca, Gündüz ve Aral (2011) okul öncesi dönem çocuklarının sosyal davranışlarını inceledikleri araştırmalarında anne ve babası öğrenim durumu üniversite ve üstü olan çocukların olumlu sosyal davranış düzeylerinin öğrenim düzeyi ilköğretim olanların çocuklarına göre daha yüksek olduğunu saptamışlardır. Seven (2007) ise ailesel faktörlerin altı yaş çocuklarının sosyal davranış problemlerine etkisi adlı araştırmasında sosyal davranış problemlerinin annenin öğrenim durumuna göre farklılaşmadığını bulmuştur. Bu araştırmada anne baba öğrenim düzeyi yüksek olan çocukların sosyal becerilerinin bazı alt boyutlarda anne baba öğrenim düzeyi düşük olan çocuklara göre daha yüksek çıkması bu araştırmada sunulan bulguları desteklemektedir.

Kapıkıran, İvrendi, Adak (2006) yaptıkları araştırmalarında okul öncesi kurumlarına devam 
etme süresi değişkenin sosyal beceriler üzerindeki etkisi incelendiğinde, okul öncesi kurumuna ikinci kez devam eden çocukların ilk kez devam edenlerden daha çok sosyal becerilere sahip olduklarını saptamışlardır. Başka araştırmalar da okul öncesi eğitim almanın ve bu eğitim süresinin çocukların ileriki yıllardaki sosyal becerilerini etkileyebildiğini göstermektedir (Öztürk 2008; Kibria \& Jain 2009 akt. Gülay \& Akman 2009). Bu araştırmada daha önce okul öncesi eğitim almış olan gelişimi risk altında olan çocukların sosyal beceri düzeyi daha önce almamış olanlara göre genelde ve çoğu alt boyutta daha yüksek çıkmıştır.

Aynı evde anne-babadan başka büyükanne, büyükbaba gibi otoritelerin olması ve dört veya daha fazla kişinin yaşamasıyla oluşan geniş aile tipi ile anti-sosyal davranışlar arasında pozitif ilişki olduğu yapılan 32 çalışmanın 31'i tarafından doğrulanmıştır (Ellis 1988). Bu çalışmama da sağlıksız kalabalık konutta yaşamanın gelişimi risk altında olan çocukların sosyal becerilerini olumsuz yönde etkilediği belirlenmiştir.

Bazı çalışmalar ebeveynin çalışma durumunun sosyal davranış problemleri üzerinde etkisi olduğunu göstermektedir. Yapılan bir araştırmaya göre, işsiz veya yarım gün çalışan anneler çocuklarını sürekli çalışanlardan daha az desteklemektedirler (McLyod et al. 1994). Seven (2007) annenin çalışma durumuna göre sosyal davranış problemi grup ortalamaları sonuçlarına göre, çalışan annelerin çocuklarının çalışmayan annelerin çocuklarına göre daha az sosyal davranış problemi gösterdikleri belirlemiştir. Bu çalışmada sosyal becerinin sadece bir alt boyutunda çalışmayan annelerin gelişimi risk altında olan çocukların sosyal beceri düzeyleri çalışan annelerin çocuklarına göre daha yüksek çıkmıştır.

Yoksul aile evlerinin fiziksel ve psiko-sosyal yapılarında bazı sıkıntılar bulunmaktadır. Genellikle evleri şehre uzak, oda sayısı yetersiz ve hane nüfusu kalabalıktır, eşya yok denecek kadar az ya da çok fazladır, anneler genellikle tükenmiş ve depresyondadır (Hatun et al. 2003). Ekonomik problemler ve başka sorunlarla uğraşan ebeveynler genellikle çocuklarına karşı ilgisiz, kayıtsız tutum sergilemektedirler. Böyle bir ortamda çocuk sosyal becerileri öğreneceği uygun bir ortamdan mahrum kalmaktadır (Yavuzer 2007; Gülay \& Akman 2009). Bu fiziksel ve psiko-sosyal yapıdan çocukların fiziksel, zihinsel ve sosyal gelişimleri olumsuz etkilenmektedir (Er 2014). Benzer bir biçimde bu araştırmada ev ortamında olumsuz fiziksel ve psiko-sosyal yapıya sahip gelişimi risk altında olan okul öncesi çocukların sosyal beceri düzeylerinin olumlu fiziksel ve psiko-sosyal yapıya sahip olanlara göre daha düşük olduğu belirlenmiştir.

$\mathrm{Bu}$ araştırmada ulaşılan sonuçlar ve buraya kadar yapılan tartışmalar doğrultusunda aşağıdaki öneriler getirilebilir:

- Çocuklar üzerinde risk yaratan etmenlerin belirlenmeli ve bunları en aza indirgeyecek erken müdahale programların tasarlanmalıdır.

- Tasarlanan erken müdahale programların uygulanması sonucunda çocuklarda oluşan değişimler gözlenmeli ve takip edilmelidir.

- Yoksul bölgelerdeki çocuklar için ücretsiz anaokulu hizmeti sağlanmalıdır.

- Yoksul çocuklar ve ailelerinin sağlık ve eğitim konusunda sosyal hizmetlerden düzenli olarak yardım görmesi sağlanmalıdır.

- Risk altındaki çocukların anne babalarına yönelik eğitimler etkili bir biçimde sürdürülmelidir.

- Sosyal becerilerin öğretimini içeren erken müdahale programları yaygınlaştırılmalı ve bu yolla çocukların topluma uyum sağlamaları kolaylaştırılmalıdır.

- Engelli çocukların sosyal beceri eğitiminde kaynaştırma uygulamalarının yanında çağdaş yaklaşımların kullanımı desteklenmelidir. 


\section{KAYNAKÇA}

Akman B. (2002). "Korunmaya Muhtaç Çocuklarla Ailesi ile Yaşayan Çocukların Kavram Gelişimlerinin ve Okula Hazırbulunuşluk Düzeylerinin Karşılaştırılması”. Toplum ve Sosyal Hizmet Dergisi 1/13 (2002) 74-85.

Aral N., Gürsoy F., Bıçakçı M. Y. \& Körükçü Ö. (2006). “An Investigation of the Social Behaviors of Children Who Attend Pre-School”. Ed. M. S. Giannakaki, G. T. Papanikos, Y. Pozios \& J. K. Richards, Institutions Research on Education (2006) 15-23. Athens.

Arpacıoğlu Ö. \& Yıldırım M. (2011). “Dünyada ve Türkiye'de Yoksulluğun Analizi”. Niğde Üniversitesi IIBBF Dergisi 4/2 60-76.

Avcıoğlu H. (2007). "Sosyal Becerileri Değerlendirme Ölçeğinin Geçerlik ve Güvenirlik Çalışması (4-6 Yaş)”. Abant İzzet Baysal Üniversitesi Eğitim Fakültesi Dergisi 7/2 (2007) 87-101.

Berk L. E. (1997). Child Development. London 1997.

Brooks-Gunn J. \& Duncan G. J. (1997). "The Effects of Poverty on Children”. The Future of Children and Poverty 7/2 (1997) 55-71.

Connor D. F. (2002). Aggression and Antisocial Behavior in Children Andadolescents. New York 2002.

Cowie H. (2012). From Birth to Sixteen Children's Health, Social, Emotional and Linguistic Development. London 2012.

Durgun Ö. (2011). “Türkiye'de Yoksulluk ve Çocuk Yoksulluğu Üzerine Bir İnceleme”. Bilgi Ekonomisi ve Yönetimi Dergisi 6/1 (2011) 143-154.

Ellis S. J. (1988). "Sociolinguistic Survey Report: Daly River Region Languages”. Ed. M. J. Ray, Aboriginal Language Use in the Northern Territory: 5 Reports (1988) 33-66.

Er R. K. (2014). "Çocuk Hakları ve Koruma Aile Refahı ve Koruma”. Ed. S. Y. Doğru, Yoksulluk ve Çocuk. Ankara 2014.

Gülay H. \& Akman B. (2009). Okul Öncesi Dönemde Sosyal Beceriler. Ankara 2009.

Hatun Ş., Etiler N. \& Gönüllü E. (2003). Yoksulluk ve Çocuklar Üzerindeki Etkileri. Çocuk Să̆lı̆̆ ve Hastalıklarl Dergisi, 46 (2003) 251-260.

Holland M., Holland L. \& Gimpel G. A (2003). Emotional and Behavioral Problems of Young Children. NY.

Kapıkıran A. N., İvrendi B. A. \& Adak A. (2006). "Okul Öncesi Çocuklarında Sosyal Beceri: Durum Saptaması”. Pamukkale Üniversitesi Eğitim Fakültesi Dergisi 19 (2006) 19-27.

Karaca N. H., Gündüz A. \& Aral N. (2011). “Okul Öncesi Dönem Çocuklarının Sosyal Davranışının İncelenmesi”. Kuramsal Ĕ̈itimbilim 4/2 (2011) 65-76.

Karasar N. (2015). Bilimsel Araştırma Yöntemi. Ankara 2015.

Mcintyre L. L., Blacher J. \& Baker B. L. (2006). "The Transition to School: Adaptation in Young Children With and Without Intellectual Disability". Journal of Intellectual Disability Research 50 (2006) 349-361.

McLoyd V. C. (1998). "Socioeconomic Disadvantage and Child Development". American Psychologist 53 (1998) 185-204.

Oktay A. (1999). Yaşamın Sihirli Yılları: Okul Öncesi Dönem. İstanbul 1999.

Öztürk A. (2008). Okul Öncesi Ĕ̆itimin İlköğretim 1. ve 3. Sınıf Öğrencilerinin Sosyal Becerilerine Etkisinin İncelenmesi. Yayımlanmamış Yüksek Lisans Tezi. Selçuk Üniversitesi, Sosyal Bilimler Enstitüsü, Konya 2008.

Schwartz J. C., Strickland R. G. \& Krolick G. (1974). "Infant Day Care: Behavioral Effects at Preschool Age". Developmental Psychology 10 (1974) 502-506.

Seven S. (2007). "Ailesel Faktörlerin Altı Yaş Çocuklarının Sosyal Davranış Problemlerine Etkisi”. Educational Administration: Theory and Practice 51 (2007) 477-499.

Taş H. Y. \& Özcan S. (2012). "Türkiye'de ve Dünya'da Yoksulluk Üzerine Bir Araştırma”. International Conference on Eurasian Economies (2012) 423-430.

Uysal H. \& Akman B. (2015). "Erken Müdahale Programlarının Erken Çocukluk Eğitimindeki Rolü: Erken Çocukluk Eğitimine Yapılan Yatırım Geleceğe Yapılan Yatırım Mıdır?”. Turkish Studies 10/3 
(2015) 1053-1068.

Wise P. H. \& Meyers A. (1991). "Poverty and Child Health". Pediatric Clinics of North America 35 (1991) 1169-1186.

Yavuzer H. (2007). Bedensel, Zihinsel, Sosyal Gelişimiyle Çocuğunuzun İlk Altı Yılı. İstanbul 2007. 